NBER WORKING PAPER SERIES

\author{
INTERNATIONAL CAPITAL \\ MOBILITY IN THE 1990s
}

Maurice Obstfeld

Working Paper No. 4534

\author{
NATIONAL BUREAU OF ECONOMIC RESEARCH \\ 1050 Massachusetts Avenue \\ Cambridge, MA 02138 \\ November, 1993
}

I am grateful to Matthew Jones and Luisa Lambertini for valiant research assistance on this paper and to Polly Allen, Tamim Bayoumi, Giuseppe Bertola, Barry Eichengreen, Jeffrey Frankel, Kaku Furuya, Morris Goldstein, Peter Kenen, Jim Nason, Franco Passacantando, and David Romer for helpful suggestions. Discussion at the April 1993 fiftieth anniversary conference for Princeton Essays in International Finance helped sharpen the paper's arguments. Any remaining errors are mine. I acknowledge with thanks financial support from: the Centre for Economic Policy Research MIRAGE project; the National Science Foundation; the Ford Foundation (through a grant to CIDER at UC-Berkeley); and the UCBerkeley Hewlett Faculty Grant program. David Backus, Tamim Bayoumi, Robert Dekle, Morris Goldstein, Kellett Hannah, Fumio Hayashi, James Poterba, and Data Resources, Inc., generously provided data and advice. This paper will be published in Peter B. Kenen (ed.) Understanding Interdependence: The Macroeconomics of the Open Economy, Princeton University Press, 1994. This paper is part of NBER's research program in International Trade and Investment. Any opinions expressed are those of the author and not those of the National Bureau of Economic Research. 


\title{
INTERNATIONAL CAPITAL \\ MOBILITY IN THE 1990s
}

\begin{abstract}
This paper surveys the performance of intemational capital markets and the literature on measuring international capital mobility. Three main functions of a globally integrated and efficient world capital market provide focal points for the analysis. First, asset-price arbitrage ensures that people in different countries face identical prices for a given asset. Second, to the extent that the usual market failures allow, people in different countries can pool risks to their lifetime consumption profiles. Third, new saving, regardless of its country of origin, is allocated toward the world's most productive investment opportunities. The paper evaluates the international capital market's performance of these roles by studying data on international interest-rate differences, international consumption correlations, international portfolio diversification, and the relations between national saving and investment rates. The conclusion is that while international capital mobility has increased markedly in the last two decades, international capital movements remain less free than intranational movements, even among the industrial countries.
\end{abstract}

Maurice Obstfeld

Department of Economics

787 Evans Hall

University of California

Berkeley, CA 94720

and NBER 
Over the past two decades, global trade in financial assets has been spurred by advances in communication and transaction technologies, by the creation of new financial products, and by a widespread trend toward deregulation of domestic and international capital-market activities. In almost all respects, the consequences of these developments remain controversial.

In theory the potential benefits of international capital mobility are clear: individuals gain the opportunity to smooth consumption by borrowing or diversifying abroad, while world savings are directed to the world's most productive investment opportunities. The size of these gains, and the extent to which they are being attained in practice, remains uncertain and furnishes an active area for research. Answers are needed urgently: high on the policy agenda in a number of countries is a choice between further integration into world or regional capital markets and the retention of traditional macroeconomic policy options.

This paper surveys the performance of international capital markets and the literature on measuring international capital mobility. Section 1 reviews the main functions and implications of capital mobility. Section 2 examines recent evidence on the world capital market's ability to arbitrage the prices of similar assets. The market's record in allowing countries to diversify risks is taken up in section 3. Section 4 focuses on interpreting divergences between national saving and domestic investment rates. Section 5 concludes.

${ }^{1}$ An excellent overview of the expanding range of international financial markets is contained in Goldstein et al. (1993). 
1. Free international capital mobility: Definition and implications Capital is freely mobile within a multi-country region when its residents face no official obstacles to the negotiation and execution of financial trades anywhere and with anyone within the region, and face transaction costs that are no greater for parties residing in different countries than for parties residing in the same country. The definition implies that national authorities do not interpose themselves between transaction partners from different countries, other than through the provision of a nationality-blind legal framework for contract enforcement.

Actual conditions may differ from this ideal of free international capital mobility. Governments can impose taxes on cross-border financial flows and payments, including certain types of reserve requirement, as well as quantitative limits and outright prohibitions. The mere threat of such measures can discourage international capital movement, as can official "moral" suasion in which threats of formal regulation may be implicit. The prospect of partial or full government expropriation of foreign-owned assets lowers the financial openness of some economies. Differences in language and business practice can raise the cost of an international financial deal relative to that of a similar deal between residents of the same country.

In measuring the strength of such barriers to international capital movement, an essential comparative benchmark is the ideal case of perfect international capital mobility, in which capital is free to move internationally and transaction costs literally are zero. This section therefore reviews the main implications of perfect capital mobility, 
implications that will be compared with recent experience in the sections to follow. A main theme of the paper is that such comparisons are seldom straightforward: many commonly used barometers of capital mobility are based on strong, of ten questionable, auxiliary assumptions about the world.

The law of one price

Perhaps the most basic implication of perfect capital mobility is that an asset's price must be the same wherever it is sold. With sufficiently detailed data it would be possible to test this implication directly on a wide array of assets. In practice, however, most tests of the law of one price compare the prices in different localities of a narrow set of closely comparable assets, namely, claims on specified future currency payments.

The dollar price of $\$ 1$ to be delivered in country $A$ one period from today is $1 /\left(1+i_{\mathbb{W}}^{A}\right)$, where $i_{\mathbb{W}}^{A}$ is the one-period nominal dollar interest rate in country $A$. In country $B$ on the same date, the nominal dollar interest rate is $i_{\$}^{B}$. Under perfect capital mobility the price of a future dollar is the same no matter where the claim to the dollar is located. Thus, the equality $i_{\$}^{\mathrm{A}}=i_{\$}^{\mathrm{B}}$ holds true (as does the corresponding equality for any other currency). Empirical studies have pursued this implication of perfect capital mobility by comparing nominal currency interest rates in different financial centers, for example, the interest rates on large dollar certificates of deposit sold in New York and those on London Eurodollar deposits of the same maturity. Strictly speaking, such assets do not guarantee the same payment in all states of nature--for example, 
the unregulated offshore Eurodollar market may be more prone to a generalized financial crisis than the onshore U.S. money market.

Nonetheless, the relation between nominal interest rates on the same currency in different financial centers is probably the least ambiguous of the commonly-used indicators of international capital mobility.

In contrast, little can be learned about international capital mobility from cross-country comparisons of nominal or real uncovered returns on different currencies. Such tests are uninformative about capital mobility because they necessarily appeal to auxiliary maintained assumptions that may be valid or not independently of the degree to which capital is mobile.

To illustrate, let $i_{\mathbb{S}}^{U S}$ be the one-period dollar interest rate in New York, $i_{\$}^{E}$ the corresponding rate in the London Eurodollar market, $i_{\mathrm{DM}}^{G}$ the nominal deutsche mark (DM) interest rate in Frankfurt, $i_{D M}^{E}$ the EuroDM interest rate, and $\hat{x}_{\$ / D M}$ the subsequent one-period percentage change in the dollar price of DM.

Consider how information about capital mobility is embedded in the ex post difference in dollar returns beween dollar deposits in New York and DM deposits in Frankfurt, $i_{\$}^{U S}-i_{D M}^{G}-\hat{x}_{\$ / D M}$ Let $E(\cdot)$ denote a conditional expectation. If one decomposes the preceding dollar return differential into

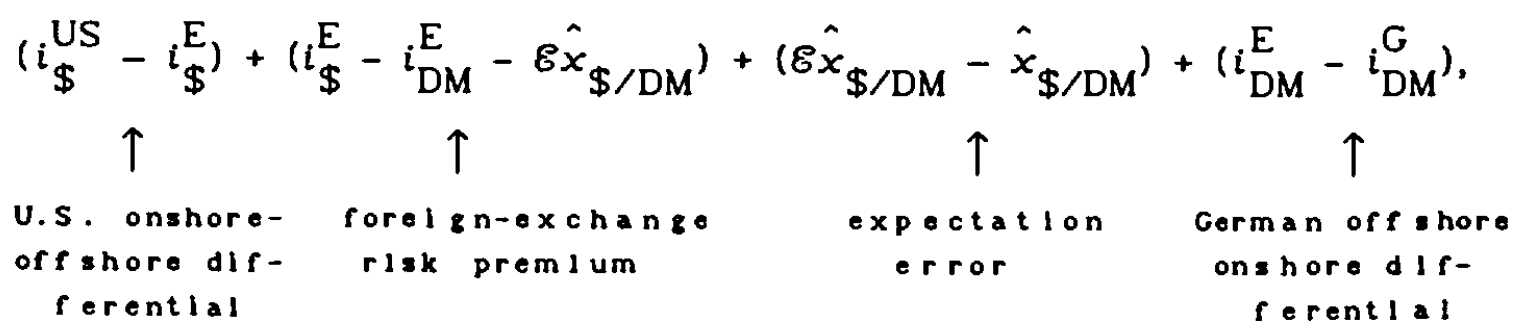


it becomes apparent that all direct information about international capital mobility is contained in the two onshore-offshore differences. Perfect capital mobility has the clear implication that both of the onshore-offshore interest-rate differentials above must be zero; but the implications of perfect capital mobility for foreign-exchange risk premia and exchange-rate forecast errors are much less obvious.

The risk premium links expected returns on assets (such as different-denomination Eurocurrency deposits) that are identical in location and in all other respects except for currency of denomination. As stressed in my 1986 paper, however, hypotheses about the relative returns on two London deposits can yield no direct information on capital mobility among financial centers.

It is similarly difficult to think of a significant direct link between capital mobility and the exchange-rate forecast errors of market participants. Conceivably the degree of capital mobility affects the information-revelation process in foreign-exchange markets, with some impact on the distribution of forecast errors. But no definite hypotheses concerning such effects have been advanced, let alone tested.

Thus, only with the aid of specific and probably irrelevant maintained hypotheses about the risk premium and expectations can one glean information about capital mobility from ex post uncovered return differentials such as $i_{\$}^{U S}-i_{\mathrm{DM}}^{G}-\hat{x}_{\$ / D M}$. Tests based on international differences in real interest rates--domestic nominal rates less expected domestic inflation--would require even more maintained auxiliary 
hypotheses than those based on uncovered returns. ${ }^{2}$ A more direct approach, yielding results vastly easier to interpret, is to analyze the one observable and relatively unambiguous indicator of capital mobility, the onshore-offshore interest differential. ${ }^{3}$ Results based on this indicator are reported in section 2.

\section{Consumption insurance}

Capital mobility allows countries to trade differential consumption risks; the effect is to provide each other with insurance against purely idiosyncratic national consumption fluctuations. In practice consumption insurance is provided by trade in a wide array of contingent and noncontingent securities: a cross-border exchange of common stock, for example, will alter the statistical distribution of both trading partners' future consumptions. The insurance function of international capital markets is best illustrated, however, by assuming that countries can trade a set of Arrow-Debreu securities, one of which entitles its owner to a specified payment on a particular date if, and only if, a

2 For a detailed discussion see Obstfeld (1986).

${ }^{3}$ Tests of covered interest parity between different countries, such as those reported by Giavazzi and Pagano (1985) and Frankel (1993), can be formulated so that they are equivalent to comparisons of onshore and offshore interest rates in the same currency. To return to the example, let $\hat{f}_{\$ / D M}$ be the one-period forward premium for DM in terms of dollars quoted in the London market. Eurocurrency arbitrage ensures that $i_{\$}^{E}=i_{\mathrm{DM}}^{E}$ $+\hat{f}_{\$ / D M}$, so the covered differential $i_{\mathrm{DM}}^{\mathrm{G}}+\hat{f}_{\$ / \mathrm{DM}}-i_{\$}^{E}$ between the Frankfurt DM market and the Eurodollar market is identical to the onshore-offshore DM differential $i_{\mathrm{DM}}^{G}-i_{\mathrm{DM}}^{E}$. 
well-defined event, or "state of nature," occurs.

Figure 1 illustrates the effect of trade in such securities for a world in which there are two countries peopled by representative agents, $A$ and $B$, two states of nature, 1 and 2, and in which consumption of a homogeneous nonproduced output is the only argument in utility functions. At the endowment point $E$, country $A$ is relatively well-endowed with state 1 consumption and country B with state 2 consumption; that is, state 1 is relatively more favorable to the fortunes of country A, state 2 to those of country B. Otherwise the two countries are, for simplicity, portrayed as being identical. If the free exchange of Arrow-Debreu securities is allowed, country A exports, and country B imports, securities that pay off in state 1; to balance this trade country A imports, and country B exports, securities that pay of in state 2 . At the resulting free-trade allocation, point $F$, both countries have raised their utilities by reducing the variability of consumption across states of nature.

Notice that this outcome is predicted by the classical principle of comparative advantage, whereby a country exports the good whose domestic autarky price is relatively low. ${ }^{4}$ The relative price of the two available Arrow-Debreu securities can be identified with the price of state 1 consumption in terms of state 2 consumption. As usual, the free-trade price, shown as $p$ in figure 1, lies between the countries' autarky prices; and in a trading equilibrium, the countries have equated their marginal rates of substitution across states to $p$, and thus to each other.

${ }^{4}$ Svensson (1988) places this result in a generalized setting. 
The implication of the particular example shown in figure 1 is that under free trade in state-contingent assets, each country will equalize its consumption across states of nature. This implication is too strong as a general empirical prediction because national differences in wealth usually would preclude consumption equalization across states of nature even in a Pareto-optimal world. In general, the implication of an efficient allocation of consumption risks is that countries' marginal utilities of consumption are perfectly correlated across states of nature; notice that if this statistical perfect correlation holds true, national marginal rates of substitution across states of nature necessarily coincide. ${ }^{5}$

The preceding empirical prediction stems from two distinct assumptions: that there is free international asset trade, and that the available set of securities available to trade is complete, so that all consumption risks are insurable. In theory either of these two assumptions can fail independently of the other; in practice, it is clear that the existence of nonverifiable contingencies and actions limits the extent to which individuals can contract to share risks. Even under

${ }^{5}$ Let $c^{A}\left(s_{j}\right)$ be country A consumption in state $j(j=1,2, \ldots, N)$, let $\pi_{j}$ be the probability of state $j$, and let $U^{\mathrm{A}}\left[c^{\mathrm{A}}\left(s_{1}\right), c^{\mathrm{A}}\left(s_{2}\right), \ldots, c^{\mathrm{A}}\left(s_{N}\right)\right]=$ $\Sigma_{j=1}^{N} \pi_{j} u^{A}\left[c^{A}\left(s_{j}\right)\right]$ be country A's expected utility. Then, with similar notation for country B, marginal utilities are perfectly correlated if, for some constant $\lambda$ and for every state $j, \pi_{j} u^{A}\left[c^{A}\left(s_{j}\right)\right]=$ $\lambda \pi_{j} u^{B},\left[c^{B}\left(s_{j}\right)\right]$. But this condition implies the equalization of marginal rates of substitution across states, $\pi_{j} u^{\mathrm{A},}\left[c^{\mathrm{A}}\left(s_{j}\right)\right] / \pi_{\ell} u^{\mathrm{A}},\left[c^{\mathrm{A}}\left(s_{l}\right)\right]=$ $\pi_{j} u^{\mathrm{B}},\left[c^{\mathrm{B}}\left(s_{j}\right)\right] / \pi_{\ell} u^{\mathrm{B}},\left[c^{\mathrm{B}}\left(s_{l}\right)\right]$. 
perfect capital mobility, there thus may be no close ex post association between national consumption levels. Other things equal, however, increasing international capital mobility should entail an increasing tendency for positively correlated consumption comovements among countries. Evidence related to this prediction is discussed in section 3 .

\section{The international allocation of investment}

If the set of state-contingent assets people trade is sufficiently rich, perfect capital mobility leads to an efficient international allocation of investment: at the margin, a decision to invest a unit of output in country B rather than country A should not affect the expected value of the flow of future world output.

The clause concerning the richness of the available asset menu is crucial, because the expected value of world output is the sum of output realizations in different states of nature weighted by state-contingent output prices. If the required set of state-contingent assets does not exist, people generally won't have common marginal rates of consumption substitution across all states of nature, and there is no presumption that investment will be efficiently allocated throughout the world. ${ }^{6}$

In a world of uncertainty and incomplete markets, it therefore is difficult to judge how close global investment patterns are to those that free capital mobility would imply. Researchers hoping to assess capital

\footnotetext{
${ }^{6}$ Under restrictive theoretical conditions, an efficient complete-markets allocation can be reached even when a complete set of state-contingent assets is not traded. For different examples, see Rubinstein (1974) and Cole and Obstfeld (1991).
} 
mobility from this perspective have been forced to rely on very rough measures of constrained investment efficiency.

A number of studies attempt to compare, directly or indirectly through an examination of capital-output ratios, the marginal contribution of installed capital to national outputs. In the presence of capital installation costs, however, this marginal product of capital need not be the same everywhere. What should be observed under capital mobility is a tendency for time-averaged marginal products of capital in various countries to converge. Correspondingly, world investment should flow disproportionately toward countries where capital is relatively more productive.

A controversial way of evaluating the efficiency of the global allocation of investment is proposed by Feldstein and Horioka (1980) and Feldstein (1983). They argue that the productivity of capital in a country is not systematically linked to the determinants of its saving rate, and infer that national saving and domestic investment rates should not be systematically associated either if capital is internationally mobile. Other things equal, a rise in a country's saving rate should cause a current-account surplus that directs the freed resources toward their most efficient worldwide uses; other things equal, an increase in the productivity of a nation's capital should cause a current-account deficit that draws in savings from abroad. Feldstein and Horioka's conclusion that this picture does not match the postwar facts has spawned a large literature that is reviewed in section 4 below. 


\section{Evidence on the law of one price}

Section 1 argued that the least ambiguous evidence on international capital mobility comes from a comparison of nominal interest rates on onshore and offshore loans of the same currency. Under perfect capital mobility, the interest rate on a three-month French franc deposit in Paris, for example, should equal that on a three-month French franc deposit in London.

Numerous studies have compared onshore-off shore interest differentials or the closely related covered interest differentials; partial surveys are in Frankel (1993) and Obstfeld (1986). Frankel (1993, table 2.4) reports statistics on the size and variability of covered interest differentials for a range of industrialized and developing countries over the period September 1982-April 1988. His conclusion is that by 1988 , departures from free capital mobility, indicated by large short-term covered interest differentials, were small for a number of countries. (Popper 1993 reaches the same conclusion regarding long-term differentials.) Included in the group of financially open economies are Canada, Germany, the Netherlands, Switzerland, the United Kingdom, Hong Kong, Singapore, Austria, Belgium, Sweden, and Japan. For other economies in Frankel's sample, most glaringly Greece, Mexico, and Portugal, substantial barriers to capital movement apparently remained as of 1988 . This latter group includes France, Ireland, and Italy, European Comunity (EC) members that adopted timetables for capital-account liberalization as part of the single-market program set out in the EC's Single European Act of 1987.

Table 1 summarizes a set of more detailed and up-to-date data for 
four industrialized countries, France (panel A), Italy (panel B), Germany (panel C), and Japan (panel D). For each currency the onshore interest rate is the three-month domestic interbank rate, the offshore rate the three-month rate in the London Euromarket. Daily Reuters data covering January 1982-April 1993 (as reported by Data Resources, Inc.,) are used. As these data did not appear to be completely accurate, suspicious observations were checked against the daily reports in the Financial Times of London and corrected when necessary.

Many empirical studies ignore the existence of information on both the ask and bid rates of interest at which banks are willing to supply and accept funds. ${ }^{7}$ Ask and bid prices are essential data in comparing rates of return internationally, however, because the rates market participants actually face include transaction costs that sum to (at most) the ask-bid spread quoted by banks. In addition, use of the distinct ask and bid rates allows the researcher to test a wider range of hypotheses about financial market links.

Under free capital mobility, borrowers have the option of using whichever market is cheapest, while lenders can place funds wherever they get the highest net return. Thus, while borrowing and lending rates in a given center need not be the same, borrowing rates should be the same in all centers where borrowing is occurring, lending rates should be the same in all centers where lending is occurring, and thus the ask-bid spread should be the same in all centers where both activities are

7 One plus the ask rate is the price of current money in terms of future money that a bank requires in order to supply current funds; it always exceeds one plus the bid rate, which is the price of current money in terms of future money that a bank will pay for current funds. 
occurring.

The first two columns of numbers in table 1 compute period daily averages of differences beween onshore and offshore bid (denoted by an underbar) and ask (denoted by an overbar) rates of interest on loans of domestic currency. As above, the subscripts on the nominal interest rate $i$ refer to currency of denomination while the superscripts refer to location, either the home country (F for France, I for Italy, G for Germany, J for Japan) or the offshore Eurocurrency market (symbolized by the letter E). The last two columns of table 1 report average onshore and offshore ask-bid spreads, which must be the same if ask and bid rates are the same onshore and of $\mathrm{f}$. The use of period averages is not ideal, because large postive and negative daily observations could cancel when the average is taken. The standard deviations given in parentheses below the average return differences of fer a rough idea of the extent to which such cancellation has occurred. Figures $2-6$, which graph the daily data on onshore-offshore bid differences, also contain some of this inf ormation. 8

In principle, two financial centers linked by free capital mobility could have different ask rates (if banks are not lending in one center) or bid rates (if no deposits are being taken in one center). This situation is unlikely to prevail for any length of time, however, and thus should not be relevant in analyzing the period averages reported in the table. Table 1 also reports the returns to a hypothetical arbitrageur who borrows in one center at the ask rate and lends in the other center

\footnotetext{
${ }^{8}$ In comparing these figures, be aware that their left-hand scales differ.
} 
at the bid rate. (The third column is the return to borrowing offshore and lending onshore, the fourth column the return to borrowing onshore and lending offshore.) Since actual arbitrage opportunities would always be exploited, hypothetical arbitrage profits are an unambiguous indicator of capital-market segmentation and must always be absent under free capital mobility. Obviously, the indicators in table 1 are not independent of each other. For example, of fshore-to-onshore arbitrage is profitable only if the onshore bid exceeds the offshore bid and the offshore ask-bid spread is sufficiently small; similarly, profitable onshore-to-offshore arbitrage requires an offshore bid above the onshore bid and a sufficiently small onshore ask-bid spread.

The first period analyzed in the table extends through the entry into force of the Single European Act in January 1987. For France (panel A) there is evidence of significant barriers to capital mobility during this period. Average ask and bid rates of interest on French franc loans are much higher offshore than onshore; and the average profitability of hypothetical onshore-to-offshore arbitrage operations is substantially positive. The interpretation of these results is that France maintained controls on capital outflows that kept domestic rates below Eurocurrency rates, particularly around realignments (Giavazzi and Pagano 1985). The especially high divergences occurring around realignments are apparent in figure 2. Note also that the ask-bid.spread is lower onshore than offshore, consistent with the relatively thinness of the Eurofranc market in the first half of the 1980s.

The last three periods shown begin roughly around the last French realignment within the European Monetary System's Exchange Rate Mech anism 
(ERM) (February 1, 1987), the deadline for abolition of French capital controls under the Single European Act (July 1, 1990), and the month of the surprise Danish rejection of the Maastricht Treaty on European monetary and political union (June 1, 1992). This last event set of a period of turbulence in exchange markets that culminated in the "flotation" of ERM currencies on August 2, 1992.

In all three of these periods the average onshore-offshore difference is on the order of 10 basis points in magnitude for both bids and asks. Hypothetical arbitrage profits are negative on average, and average ask-bid spreads much closer in the two markets. Clearly, the integration of onshore and offshore money markets is much higher than before 1987.

The final period, that of the ERM crisis, is clearly more turbulent than the previous two: the standard errors of returns are much higher, as are ask-bid spreads. As figure 3 (an enlargement of the January 1992-April 1993 data) shows, some large gaps between onshore and offshore bid rates emerged during September 1992, when the franc first came under concerted attack by speculators. Similar data have been identified as evidence of lingering capital controls by some commentators. 9

Notice in figure 3 that the onset of ERM turbulence is the dividing point between a period in which onshore bid rates usually exceed of shore rates by a small amount, and one in which the reverse is true. This pattern would be consistent with a shift from a regime in which the

${ }^{9}$ The Economist of fered this interpretation of the unusual onshoreoffshore French franc differentials. See "A Funny Thing Happened," Economist, October 10, 1992, p. 97. 
market attaches a small but positive probability to future capital controls, to one in which mild of ficial discouragements to capital outflow are actually in place. Between September 1992 and April 1993 there are, however, only four instances of pure profits from onshore-to-of fshore arbitrage, all in 1992: on September 22 and 23, on November 24, and on December 1.

The case of Italy (panel B of table 1) also shows evidence of restricted capital mobility before February 1987. Average offshore bid and ask rates both exceed onshore counterparts, and there exists a small mean ( 15 basis point) profit from undertaking a hypothetical onshore-to-offshore arbitrage. ${ }^{10}$ As Giavazzi and Pagano (1985) observed using a shorter data sample, domestic Italian interest rates diverge less from the corresponding offshore rates than do French domestic rates during this initial period. Nonetheless, the data are consistent with the view that Italy, like France, restricted capital outflows and thus held domestic interest rates artificially low. As in the case of France, the ask-bid spread before February 1987 is higher offshore.

The next subperiod, February 1, 1987-June 30, 1990, shows some convergence to offshore conditions: average onshore rates now rise a bit above average of fshore rates, average arbitrage opportunities disappear, and the absolute mean difference between of fshore and onshore spreads narrows.

After July 1, 1990 average onshore rates actually rise further above offshore rates and apparent opportunities for profitable offshore-to-

${ }^{10}$ The large standard error on this small mean value implies episodically large notional profit opportunities. 
onshore (that is, inward) arbitrage open up (see figure 4). Italy adopted a narrow ERM band for the lira in January 1990 and then removed its remaining capital-account restrictions in May. Subsequently, Italy's desire to avoid realignment clashed increasingly with the lira's ongoing real appreciation and with the growth in domestic public debt. Plausibly, the onshore interest interest premium reflected market fears that capital controls might be reimposed in the future to shore up Italy's increasingly strict interpretation of its ERM commitments. Consistent with this view is the behavior of the average onshore premium after June 1, 1992, a period that includes Italy's abandonment of the ERM for a float on September 17, 1992: the average premium drops and average arbitrage profits disappear as one key motive for reimposing capital controls evaporates." After September 1, 1992 the sole instance of a pure profit from outward arbitrage occurs on January 4, the first business day of 1993.

Panel C of table 1 shows that before February 1987, Germany's onshore interest rates were on average slightly above offshore rates, consistent with of ficial measures discouraging capital inflow (see also figure 5). There is even a slight average profit from hypothetical inward arbitrage during this period. Ask-bid spreads, however, are essentially the same in the onshore and offshore markets throughout the full sample period.

In all three subperiods after February 1987, onshore and of fshore

"Changes in Banca d'Italia required-reserve policy may also have played a role in these developments. See Goldstein et al. (1993, p, 73). 
rates are very close on average and mean arbitrage profits are negative. Some large onshore premia emerge during the fall 1992 ERM crisis, however: over the period September 1992-April 1993, offshore-to-onshore arbitrage appears profitable on 51 out of 242 business days! This pattern may reflect continuing government intervention in the capital markets. Goldstein et al. (1993, p. 56) mention the "gentlemen's agreement" whereby the Bundesbank may impose high marginal reserve requirements on loans in excess of a certain limit to German banks from their London branches.

For Japan (panel D of table 1) a less complete set of data were available from Reuters. The available data show a very small average difference between onshore and offshore bid rates over the first sample subperiod, consistent with Japan's substantial liberalization of capital movements in December $1980 .^{12}$

Surprisingly, the subperiod beginning with February 1987 shows a 60 basis-point average excess of offshore over onshore bid rates; figure 6 makes clear that this differential is much too long-lived to ascribe to the time-of-day difference in the Japanese onshore and offshore data. Ueda (1993, p. 19) suggests that before November 1988 the Bank of Japan used heavy administrative guidance to separate the interbank loan market from both the onshore certificate of deposit market and the Euroyen market; during the subperiod in question, the Bank of Japan wished to hold interbank rates below onshore and offshore open-market rates. ${ }^{13}$ Thus,

\footnotetext{
${ }^{12}$ Marston (1993a) examines differences in Japanese and U.S. short-term interest rates and reviews related literature.

13 In November 1988 the Bank took measures liberalizing the interbank
} 
the onshore-offshore gaps in figure 6 indicate a segmentation within the domestic financial market that, as a side effect, insulated part of that market from global forces.

Over the last two subperiods the mean onshore bid exceeds the mean offshore bid by relatively small amounts. The ask-bid spread in the Euroyen market is so slim that even the small onshore premium implies positive average arbitrage profits from borrowing offshore and investing onshore. These divergences grow stronger in the period starting with June 1992. In light of the data's imperfections it is hard to put too much weight on these numbers as indicators of capital-market restriction. Faced with a punctured "bubble" economy and a rising yen in these years, however, Japanese of ficials did have incentives to discourage capital inflows through informal means.

What conclusions follow from these and similar data for other industrial countries? For the four countries in table 1 as well as for others such as the United States and United Kingdom that have liberalized international financial transactions, there are extremely close links between onshore and offshore money markets, links that increased in strength over the 1980s. The data also show, however, that even for these countries actual or prospective government interventions remain a significant factor in times of turbulence. And in most cases governments still have instruments that can drive at least temporary wedges between onshore and offshore interest rates. European countries that have not completely opened their capital accounts, such as Spain, Portugal,

market. 
Ireland, and Greece, openly retain such instruments; all four used them during the ERM currency crisis that began in $1992 .{ }^{14}$ Even most of these countries have strong links to world capital markets. For example, Ireland's onshore and of fshore interest rates were close on the whole during the period from the late 1980 s to 1992 (see figure 7).

Matters are different in the developing world, where high explicit or implicit barriers to capital flows remain common. Discussions of financial liberalization and international interest-rate linkages for developing regions can be found in Calvo, Leiderman, and Reinhart (1992), Glick and Hutchison (1990), and Mathieson and Rojas-Suarez (1993).

\section{The diversification of global consumption risks}

This section examines evidence on the world capital market's success in helping countries trade consumption risks to achieve a mutually preferable allocation of consumption across states of nature. Researchers have taken several approaches to this question. Some look directly at national or regional correlations in consumption. Others look at the extent of trade in explicitly state-contingent assets. As will become apparent in the discussion, the implications of such data for capital mobility are ambiguous unless specific and strong side assumption are made about the functioning of domestic and international capital markets. Much recent research is aimed at testing these assumptions, and as difficult as the task is, it is justified by the need better to understand the current and potential risk allocation role of world

${ }^{14}$ See Goldstein et al. (1993) and Committee of Governors of the Central Banks of the Member States of the European Economic Community (1993). 
capital markets.

International consumption correlations

A simple maximization problem illustrates how global consumption allocations would behave in the ideal case of perfect international trade in a complete set of state-contingent assets. Since the resulting allocation is Pareto-optimal, its properties can be read of $f$ from the first-order conditions that a world planner would derive in maximizing a social welfare function linear in national utilities.

An analytically convenient starting point is the assumption of a representative national agent for each country. This assumption, which will be discussed further below, amounts to supposing that risks have already been shared optimally within each country, leaving only the remaining gains from trade between countries as the analytical focus. Country $j$ 's representative agent maximizes (from time $t=0$ ) the expected utility functional

$$
u_{0}^{j}=\varepsilon_{0}\left\{\sum_{t=0}^{\infty} \delta^{t} u^{j}\left(c_{t}^{j}, x_{t}^{j}\right)\right\},
$$

where $\delta \in(0,1)$ is a discount factor, $c_{t}^{j}$ (as before) is consumption of an internationally tradable good and $x_{t}^{j}$ is consumption of a nontradable good (possibly leisure). ${ }^{15}$

${ }^{15}$ This formulation already imposes strong restrictions on national utility functions (e.g., time- and state-separability), and more will be imposed later. Without some assumptions on preferences, however, no observable implications of international risk sharing could be derived. 
Given $N$ countries and fixed country welfare weights $\omega^{j}, j=1,2$, $\ldots, N$, the planner maximizes the social welfare function

$$
W_{0}=\sum_{j=1}^{N} \omega^{j} U^{j}
$$

by distributing the tradable consumption available on each date, and in each state, among the $N$ countries. If $c_{t}^{W}$ is world tradable consumption on date $t$, a necessary condition for distributing it efficiently among countries is

(1) $\omega_{j} u_{1}^{j}\left(c_{t}^{j}, x_{t}^{j}\right)=\omega_{\ell} u_{1}^{\ell}\left(c_{t}^{\ell}, x_{t}^{\ell}\right) \quad$ (for all countries $j$ and $\ell$ ), where $u_{1}(c, x)$ is a partial derivative with respect to c. Equation (1) implies that for tradable goods, marginal rates of substitution across states of nature are equalized internationally in an efficient allocation. Because nontradables cannot be shifted among countries, however, the corresponding condition on marginal utilities from the nontradable need not hold.

To derive more specific predictions from (1), suppose that no nontradables $x^{j}$ are consumed and that utility functions have the specific form $u^{j}\left(c^{j}, x^{j}\right)=\frac{1}{1-R_{j}}\left(c^{j}\right)^{1-R_{j}}$. Then if $\hat{c}_{t} \equiv \log c_{t}-\log c_{t-1}$, (1) implies

(2) $\hat{c}_{t}^{j}=\left(R_{\ell} / R_{j}\right) \hat{c}_{t}^{\ell}$

that is, with isoelastic preferences logarithmic growth rates of consumption are perfectly correlated ex post in all countries. If 
countries have different (fixed) rates of time preference, equation (2) will contain a constant term but the perfect correlation prediction will still hold true. If capital is internationally mobile but asset markets are incomplete, conditions weaker than perfect correlation will characterize the relationship between countries' ex post intertemporal marginal rates of substitution. As noted above, informational asymmetries generate moral hazards that make certain risks uninsurable. In the extreme case where only a riskless consumption-indexed bond is traded among countries, expected, but not ex post, intertemporal marginal rates of substitution will coincide internationally. This case is the one analyzed in stochastic versions of the life-cycle/permanent-income hypothesis. If only nominally risk-free bonds are traded, expected intertemporal marginal rates of substitution for money (rather than consumption) will be equalized. ${ }^{16}$ More generally, ex post cross-country differences in intertemporal marginal rates of substitution will be uncorrelated with any random variables on which international contracts can be written. Under incomplete markets asset trade allows the sharing of some, but not all, risks.

To compare reality against the predictions of the specific complete-markets model just set out, table 2 examines the correlations of national annual real private consumption growth rates, measured in per capita terms, with rest-of-world per capita private consumption growth over two eras in the development of world capital markets, 1951-72 and

\footnotetext{
${ }^{16}$ See Kollmann (1992) and Obstfeld (1989).
} 
1973-88. ${ }^{17}$ The consumption data come from the Penn World Table assembled by Summers and Heston (1991); the "world" shown in table 2 consists of countries with continuous $1950-88$ data rated of quality $C_{-}$or above by Summers and Heston.

All the correlation coefficients, denoted $\rho(\hat{c}, \hat{c} W)$ (where $c^{W}$ is restof-world real per capita consumption), are below the value of 1 that would obtain with isoelastic utility were capital perfectly mobile and markets complete. Several regularities in the results are, however, apparent.

For the post-1973 period--a period during which the volume of international financial transactions has increased enormously relative to world output--consumption growth in industrial countries is on average somewhat more highly correlated with rest-of-world consumption growth than is consumption growth in developing countries. Within the group of industrial countries, however, there are sharp differences.

For a majority of EC members, domestic and world consumption growth are relatively strongly correlated; Greece, Portugal, and Spain, which still maintain capital controls, as well as Italy, which did so through early 1990, are in the minority, as is, surprisingly, Luxembourg. For virtually all EC countries the correlation coefficient rises between the first and second subperiods (most dramatically for Germany). Multiple

${ }^{17}$ The current model implies that each country's consumption growth is perfectly correlated with world consumption growth under the assumption that all countries have the same value of $R_{j}$ Looking at correlations with world consumption growth, rather than at the customary pairwise consumption-growth correlations, economizes on the number of estimates reported. This procedure also has some potential statistical advantages (see Obstfeld 1994). 
regressions show that this last result persists even after one controls for possible parallel responses to the two OPEC oil-price shocks. ${ }^{18}$

For industrial countries outside the EC, the consumption correlations tend to be lower except for Switzerland and Japan. Moreover, apart from those two countries, there is a tendency for the correlations to decrease, not increase over time. To explain the contrast with the EC countries would require a country-by-country analysis. One general factor, however, may be the exchange-rate regime: these countries opted for greater exchange-rate flexibility than the EC countries in the early 1970s partly because they desired to decouple domestic from world consumption growth. The Japanese example shows, however, that floating exchange rates and even capital controls (which persisted in Japan through 1980) need not rule out a strong coherence between domestic and world consumption growth.

One way to highlight the change in German and Japanese consumption behavior after 1973 is through a simple regression. Let $y^{j}$ denote country $j$ 's real per capita GDP, in $v^{j}$ its real per capita investment, and $g^{j}$ its real per capita government spending. Absent international asset markets, domestic per capita consumption $c^{j}$ would be limited to $y^{j}-i n v^{j}-g^{j}$. The regression

$$
\hat{c}_{t}^{j}=\alpha_{0}+\alpha_{1} \hat{c}_{t}^{W}+\alpha_{2} \Delta \log \left(y_{t}^{j}-i n v_{t}^{j}-g_{t}^{j}\right)+\varepsilon_{t}^{j}
$$

gives an indication of whether consumption growth is more strongly

${ }^{18}$ See Obstfeld (1994) for further discussion. 
associated with global or with domestic factors. ${ }^{19}$ The Summers-Heston data lead to the following results:

Germany

$1951-72$

$$
\alpha_{1}=\underset{(0.33)}{-0.18,}, \alpha_{2}=\underset{(0.13)}{0.76}
$$

$1973-88$

$$
\alpha_{1}=\underset{(0.32)}{1.07}, \alpha_{2}=\frac{0.02}{(0.20)}
$$

$$
\begin{aligned}
& \alpha_{1}=\underset{(0.37)}{-0.15}, \alpha_{2}=\frac{0.76}{(0.13)} \\
& \alpha_{1}=\underset{(0.42)}{1.18}, \alpha_{2}=\underset{(0.26)}{0.35} .
\end{aligned}
$$

The regressions show a stunning reversal for both countries. In the earlier period national consumption growth is insignificantly correlated with world consumption growth but moves nearly one-for-one with the growth of GDP net of investment and government spending. From 1973 on the opposite is true.

A fundamental identification problem is suggested by the columns in table 2 labeled $\rho\left(\hat{y}, \hat{y}^{W}\right)$, which report correlations between national per capita output growth rates and rest-of-world per capita output growth. For most of the industrial countries these correlations rise between the two subperiods shown. Thus, while any increase over time in the consumption between national and world consumption growth could be due to increased risk sharing through the international capital market, it could also be explained by other mechanisms, such as a naive Keynesian consumption function in which consumption merely tracks current output or by one of the richer behavioral models discussed by Carroll and Summers

${ }^{19}$ See Obstfeld (1994) for more discussion of this equation and its estimation. 
(1991). The table 2 correlations $\rho(\hat{c}, \hat{y})$ between domestic output and consumption growth are high in most cases, but are of ten well below unity.

Again, only country-by-country analysis can resolve this question. For example, tests reported in Obstfeld (1994) show that the high post-1973 correlation of Japanese with world consumption growth may reflect only the high correlation coefficient between world consumption and Japanese output (0.72), coupled with the high correlation of Japanese consumption and output. In contrast, German output growth also has a very high correlation coefficient with world consumption growth (0.84), yet adds no significant explanatory power to a regression of German on world consumption growth. These regressions are somewhat analogous to those Campbell and Mankiw (1991) examine in modeling departures from the permanent-income theory.

Among the developing countries in table 2, a few have reasonably high post-1973 correlation coefficients with world consumption growth--notably, a few Central American countries, Chile, Cyprus, and Thailand. But this is not the norm. Notice that the developing countries with high post-1973 values of $\rho\left(\hat{c}_{,} \hat{c}^{W}\right)$ also have high values of $\rho\left(\hat{y}_{,} \hat{y}^{W}\right), a$ pattern probably due to the rudimentary financial markets available in most of these countries over much of the sample period.

Before drawing strong conclusions from table 2 about feasible gains from risk-sharing, recall that (2) was based on some restrictive auxiliary assumptions, for example, the assumption that nontradables are not consumed. If some consumption goods are nontradable, there is no necessity for national consumptions to be perfectly correlated: risks 
relating to the consumption of nontraded goods may be impossible to share (Stockman and Dellas 1989). At best, consumption of tradables will obey (2) if the utility function $u^{j}\left(c^{j}, x^{j}\right)$ is separable (but still isoelastic in $c^{j}$ ). In more complicated models, even this simple property can fail despite complete markets. 20

By investigating the stochastic consequences of a labor/leisure tradeoff and/or nontradables, several studies have tried to reconcile consumption correlations such as those shown for the industrial countries in table 1 with complete markets and perfect capital mobility.

Backus, Kehoe, and Kydland (1992) and Stockman and Tesar (1990) observe that the pairwise correlation coefficients between (Hodrick-Prescott (1980) filtered) industrial-country consumption levels tend to be lower than the corresponding output correlations. This property of the data is quite evident in table 2: after 1973, $\rho(\hat{c}, \hat{c} W)$ exceeds $\rho\left(\hat{y}, \hat{y}^{W}\right)$ only for Denmark, Finland, Sweden, and Switzerland among 23 industrial countries. Backus, Kehoe, and Kydland fail to replicate this pattern using a plausibly calibrated two-country intertemporal production model with uncertainty.

Stockman and Tesar introduce nontradable consumption into a similar equilibrium business-cycle model and find that the addition of preference shocks allows a closer approximation to the empirical correlation coefficients for national consumptions and outputs. Devereux, Gregory, and Smith (1992) show that a specific utility nonseparability between consumption and labor supply allows an equilibrium business-cycle model

${ }^{20}$ Stulz (1981) addresses these questions in a general setting. 
to replicate the U.S.-Canada consumption-correlation coefficient. They do not, however, subject their model to the tougher test of fitting other moments of the data. Van Wincoop (1992a, table 1) adjusts annual 1970-88 consumption data from the United Nations System of National Accounts for both nontradability and durability. He finds that for most industrial countries, the correlation between the growth of adjusted domestic per capita consumption and adjusted world per capita consumption is much higher than in table 2 above (albeit still imperfect). His calculations do not, however, control for the possibility that correlations are also higher among the growth rates of similarly adjusted per capita domestic outputs.

Lewis (1993) carries out a panel study of the growth of nondurable, tradable consumption using data from 48 countries sampled at five-year intervals over 1970-85. Remarkably, she finds that while domestic output growth is a strong and significant determinant of total consumption growth in her panel, its effect on nondurable, tradable consumption growth is statistically insignificant; furthermore, domestic output growth explains less than 1 percent of the dependent variable's variance (as opposed to about two-thirds of the variance of total consumption growth). Although imprecisely estimated, the coefficient of output growth in Lewis's equation for nondurable, tradable consumption remains sizable. In light of possible measurement errors, and her panel methodology's merging of countries with different degrees of financial openness, a judicious conclusion is that durability and nontradability go part but probably not all of the way in explaining why total consumption growth is highly correlated with domestic output growth. Lewis does not look at 
the influence on consumption of idiosyncratic factors other than income growth, so her results do not explain why, as in van Wincoop's (1992a) study, international consumption correlations remain imperfect even after attention is restricted to nondurable tradables.

The message of this body of work seems to be that after allowing for nontradables and durables, equilibrium complete-markets models that assume perfect capital mobility still cannot provide a satisfactory explanation of international consumption correlations unless unexplained preference shifts are assumed as in Stockman and Tesar (1990). Taste shocks are not inherently implausible, but until they are modeled more fully, there is no way of telling if the heavy explanatory burden they bear in the Stockman-Tesar model is reasonable. ${ }^{21}$

An alternative approach starts by acknowledging that the assumption of complete asset markets is glaringly at odds with the facts. Events such as job loss generally are not completely insurable because of the potential for moral hazard. More generally, labor incomes cannot be privately insured against all contingencies. Some shocks simply cannot be foreseen with sufficient clarity to be provided for in contracts. Thus, even with perfect capital mobility, there is no reason to expect high correlations even between the tradable-goods consumptions of different countries.

Empirical studies of U.S. micro-data, such as Cochrane (1991), Mace

\footnotetext{
${ }^{21}$ Canova and Ravn (1993), Lewis (1993), and Obstfeld (1994) all allow for preference shocks in their formal tests of consumption risk-sharing models. In tests on quarterly data for 9 OECD countries, Canova and Ravn find little evidence against moment restrictions implied by a model based on equation (2) above. They do, however, reject long-run implications of the model.
} 
(1991), and Mankiw and Zeldes (1991), confirm that even within modern industrial economies there are unexploited opportunities for risk sharing. 22 In line with this conclusion, van Wincoop (1992b) finds that the correlations among (Hodrick-Prescott filtered) per capita consumption levels in Japanese prefectures are well explained by a simulation model in which domestic Japanese financial markets are incomplete and subject to limited participation. 23

These considerations have three implications for the class of models discussed so $\mathrm{far}$ in this section. First, the representative national consumer is a hypothetical construct that, while perhaps useful for illustrating the incremental gains from international compared with national risk-sharing, gives a misleading picture of how national consumption levels actually are determined. Second, imperfect correlations among industrial-country consumptions are likely to be in large measure the result of asset-market incompleteness rather than international capital-market segmentation. Third, studies of international consumption-correlatedness that counterfactually assume complete markets probably cannot throw much light on the international mobility of capital. A more fruitful approach is to consider models admitting alternative financial-market structures (for example, Cole 1988), and ultimately models in which market incompleteness arises

22 Indeed, Altonji, Hayashi, and Kotlikoff (1992) find such unexploited opportunities even within extended U.S. families. Deaton (1992, p. 37), who surveys related microeconomic literature, reminds us that moral hazard problems are relevant even within families.

${ }^{23}$ Van Wincoop (1992c) shows that such a model also can rationalize cross-country consumption correlations. 
endogenously (for example, Gertler and Rogoff 1990 and Lucas 1992).

Comparing regional and international risksharing

If asset markets are incomplete, is there any way that consumption correlations or related measures can throw light on the extent of international capital mobility? Atkeson and Bayoumi (1992) propose an imaginative approach to this problem: they use the measured extent of regional risk-sharing within the United States as a benchmark against which the efficiency of international risk-sharing among a group of industrial countries can be judged. In principle, this methodology can help one judge the extent to which low international consumption correlations are due to international asset-trade barriers as opposed to incomplete markets.

The findings, though generally pointing to higher regional than international financial integration, are somewhat ambiguous. Regional financial transfers within the U.S. appear to be much larger in absolute value than resource transfers into or out of the main industrial countries, suggesting more extensive asset trade within the U.S. In contrast, U.S. regional growth in real retail sales (a consumption proxy) is no less correlated with regional ouput growth than is OECD national consumption growth with national output growth.

Atkeson and Bayoumi also find that in U.S. data, regional shifts in capital income are virtually uncorrelated with regional capital product but are highly correlated with U.S. capital income. In Europe, national capital incomes, though uncorrelated with national capital products, seem much less correlated than in the U.S. with total European capital income. 
Atkeson and Bayoumi interpret this result as indicating better capital-income diversification within the U.S. than within Europe, but an opposite interpretation is entirely compatible with their findings: U.S. investors do not hold assets abroad, whereas Europe is open enough financially that much of its capital income is earned on other continents. The consumption correlations in table 2 do not obviously contradict the alternative view.

Table 3 provides another regional/international comparison using yearly data assembled by Robert Dekle on per capita consumption and income (which is interpreted here as an output proxy) in 45 of the 47 Japanese prefectures over $1975-88 .{ }^{24}$ The column labelled $\rho\left(\hat{c}, \hat{c}^{J}\right)$ shows the correlation of prefectural per capita private consumption growth with mean per capita consumption growth in the other 44 prefectures. These numbers are similar on the whole to those reported for countries in table 2; slightly less than half the time, the consumption correlations are below the corresponding income correlations, labeled $\rho\left(\hat{y}, \hat{y}^{J}\right)$. The column labeled $\rho(\hat{c}, \hat{y})$ shows the correlation between per capita consumption and income growth by prefecture. In about two-thirds of the cases these numbers are rather high, as are most of the corresponding numbers for national economies in table 2; but in other cases the correlations are relatively low and sometimes even negative. While there is thus some limited evidence that risk sharing within Japan may be more efficient than is risk sharing among industrial countries, this is not evident in

${ }^{24}$ See Dekle (1993) for a description of these data and an econometric analysis of their implications for inter-regional capital mobility. 
the intra-national consumption correlations.

In contrast to these results for Japan, Crucini (1992) finds in annual 1971-90 data that consumption growth rates among Canadian provinces generally are more highly correlated than are provincial output growth rates or different countries' consumption growth rates.

A problem in comparing regional risk sharing within nations with risk sharing among nations when asset markets are incomplete is that a predominance of uninsurable country-specific shocks can create a spurious impression of greater risk-sharing within than between countries. Another drawback of the approach is that more goods are nontradable across national borders than across regional borders, so that, other things equal, one would naturally expect inter-regional consumption correlations to be higher than international ones. Finally, government-mediated transfers and spending play a significant role in pooling risks within countries. It is conceivable that any finding of higher inter-regional than international consumption correlation is entirely an artifact of government intervention. Despite these and other ambiguities, refinements of this general approach promise a better understanding of how international and intranational financial linkages differ.

The extent of international portfolio diversification

Further evidence on the world capital market's promotion of international risk sharing comes from a direct examination of international portfolio positions. The consensus of studies such as French and Poterba (1990, 1991), Golub (1991), and Tesar and Werner (1992) is that there is a substantial "home bias" in the portfolios of 
industrial-country investors. French and Poterba and Tesar and Werner argue that conventional models of portfolio choice can explain these patterns only if domestic investors have a much more optimistic view of the expected return on domestic assets than do foreign investors. Alternatively, imperfect capital mobility simply could make extensive international diversification prohibitively costly or infeasible. But in view of the efficiency of international interest-rate arbitrage among industrial countries (section 2), no one believes that costs or official impediments to foreign investment are universally high enough fully to explain the home bias in equity portfolios. Thus, there is an international diversification puzzle. 25

One widely-cited estimate reports that in December 1989 U.S. investors held 94 percent of their stock-market wealth in home equities, Japanese investors 98 percent, and U.K. investors 82 percent (French and Poterba 1991). These figures apparently do not control for holdings by "home"-based corporation of assets located abroad, for example, Nissan's Sunderland, U.K. auto plant. Investors may diversify, moreover, through holdings of assets other than equities, such as direct investments and bonds. French and Poterba (1991) report, for example, that 79 percent of German corporate equity was domestically owned at the end of 1989, which suggests a substantial home bias in German investors' portfolios.

Germany's December 1991 gross external assets, however, amounted to 72.9 percent of its GDP and its gross external liabilities to 51.4 percent of

${ }^{25}$ Dumas (forthcoming) surveys models of international portfolio choice from the perspective of the international diversification puzzle and other asset-market puzzles. 
its GDP--numbers which could be indicative of extensive foreign diversification. ${ }^{26}$ Such diversification might help explain the robust correlation of German with world consumption growth noted above.

The German case may be atypical; U.S. and Japanese investors, for example, probably have not used foreign diversification opportunities as extensively. ${ }^{27}$ Several explanations for this puzzle have been proposed. Stockman and Dellas (1989) argue that the presence of nontraded goods and services may impart a significant home-asset bias to investors' portfolio decisions. The empirical importance of home-asset bias due to nontradables remains to be established, however. ${ }^{28}$ Another explanation hinges on a different type of general-equilibrium consideration: if an investor's labor income (which generally is nontradable) is negatively correlated with her domestic capital income, the gains from foreign diversification of capital income are reduced. This argument suggests that the appropriate criterion for evaluating the gains from international diversification is the scope for raising mean consumption growth and lowering its variance. And if this scope is limited, international diversification may be discouraged by even minimal

${ }^{26}$ Data on total German external assets and liabilities come from Deutsche Bundesbank (1993, p. 45). I have supplemented these numbers with a 1991 GDP estimate of $\$ 1.58$ trillion.

27 For the U.S., external assets were 34.5 percent of GDP at the end of 1991 and external liabilities 40.9 percent. The corresponding Japanese figures are 59.2 percent (external assets) and 47.9 percent (external liabilities). Position data come from Deustsche Bundesbank (1993, p. 45). My GDP estimates are \$5.68 trillion for the U.S. and \$3.39 trillion for Japan. These figures show considerable growth over the comparable 1987 figures reported by Brainard and Tobin (1992, p. 536). Their numbers show that for the U.K. assets and liabilities already exceeded GNP in 1987. 28

Alternative theoretical models of home-asset bias are proposed by Eldor, Pines, and Schwartz (1988) and by Tesar (1993). 
investment barriers such as transaction costs.

Cole and Obstfeld (1991) use a model calibrated to U.S. and Japanese data to illustrate that the welfare gains from aggregate risk-sharing among industrial countries may be as small as one-fifth of 1 percent of GNP per year. ${ }^{29}$ Golub (1991) takes issue with this result, arguing on the basis of 1970-87 data that despite small aggregate gains, Japanese and U.S. recipients of exclusively corporate income cannot pool risks with human or noncorporate capital and, as a result, would gain substantially from freer asset trade. Thus, strong incentives for cross-border diversification might remain. Van Wincoop's (1992c) calibration model similarly implies that owners of capital can face significantly stronger incentives to diversify than aggregate consumption figures suggest. A useful extension of this work would attempt to distinguish empirically between the labor incomes of stockholders and nonstockholders.

Brainard and Tobin (1992) and Baxter and Jermann (1993) argue that because human capital is largely nontradable, its owners have a strong incentive to go short in domestic equities and long in foreign equities when the returns to domestic human and physical capital are positively correlated. Whether this deepens the home bias puzzle in practice requires further research on the international correlations among returns to human and physical capital. Golub (1991), for example, shows that human and physical capital returns (measured by labor income and corporate profits, respectively) appear negatively correlated for Japan,

\footnotetext{
${ }^{29}$ See also Mendoza (1991) and Obstfeld (1992), who present alternative
} estimates of small industrial-country gains from asset trade. 
and that the optimal portfolio of a Japanese worker can be skewed toward home equities. This inference, however, depends on Golub's assumption that the national-income account proxies he uses to measure returns to human capital and equity do not distort the true statistical relationship between those variables.

Even the magnitudes of the aggregate gains from risk sharing among industrial countries are in dispute. Van Wincoop (1992a), who examines a larger sample of countries, assumes a lower rate of time preference, and allows for some nondiversifiable consumption risk, finds gains from risk sharing much larger than those found by Cole and Obstfeld. Obstfeld (forthcoming, a) shows that financial integration can bring very large welfare gains if diversification has effects on investment and output growth rates. Before the puzzle of low diversification is resolved, more work on understanding both the magnitude and distribution of the gains from international risk sharing is needed.

The importance of transaction costs also is unclear. Cole and Obstfeld (1991) argue that small transaction costs--for example, the extra paperwork needed to obtain a tax credit for asset income withheld by a foreign government--could substantially discourage international diversification. Backus, Kehoe, and Kydland (1992) confirm this as a theoretical possibility. They show that introducing small costs of international transactions into their empirically calibrated model leads to an equilibrium very close to the autarky allocation. This result, however, is based on a representative-agent model which may seriously understate individual, as opposed to aggregate, gains from trade. Tesar and Werner (1992) find that the turnover rate for foreign equity 
investments is higher than that in domestic equity markets, and offer this difference as evidence that transaction costs are not important in promoting international equity-market segmentation. Transaction costs other than turnover costs could, however, be important impediments to cross-border investments.

To summarize, the available data on international portfolio positions suggest that many industrial countries are not diversified nearly to the extent that standard models of global portfolio choice would predict. The reasons could range from transaction costs to internationally asymmetric information (Gehrig 1993) to differential tax treatment of domestic and foreign investors (Gordon and Varian 1989) to irrational expectations concerning the relative returns on domestic and foreign investments. ${ }^{30}$ Future progress in unraveling the apparent puzzle may come from a more disaggregated analysis of different income groups' investing behavior. Even at the aggregate level, more detailed information on national balance sheets would give a better perspective from which to evaluate the risk and return characteristics of national portfolios.

Such analyses would throw light on a related outstanding puzzle: how to reconcile convincingly the possibly small aggregate gains from pooling national consumption risks with the apparently large unexploited gains to expected wealth maximizers from international equity diversification. This is no small task. The literatures on stock-market volatility and the

${ }^{30}$ Morris Goldstein has suggested that there is also a noticeable regional bias in international investment, a phenomenon consistent with the notion that informational barriers to international investment are important. 
equity-premium puzzle show how hard it is to rationalize the behavior of equity returns on the basis of simple optimal-consumption models. Mankiw and Zeldes's (1991) observation that United States stockholders have more variable consumption than nonstockholders could be part of an explanation if true in other industrial countries. Even this finding does not enable Mankiw and Zeldes fully to resolve the equity-premium puzzle for the United States.

\section{Gains from risk-sharing by developing countries}

Even if it is true that industrial countries would reap only modest gains from further international pooling of risks, there is lttle doubt that developing countries could benefit enormously.

Lucas (1987) proposed the thought experiment of eliminating the variability of United States consumption around its trend path. For the U.S. and for most other industrial countries, the aggregate or social benefit this hypothetical event would confer is small--far less than 1 percent of GNP per year in most cases. These small numbers are upper bounds on the aggregate gains to industrial countries from international risk sharing (absent dynamic investment effects).

Even the aggregate cost of consumption variability is significant for most developing countries. For a representative sample, table 4 shows the welfare gain per year from eliminating consumption variability, expressed as a percent of annual consumption. The calculations use the Summers-Heston (1991) data on per capita consumption and assume that the natural logarithm of real per capita consumption follows a random walk with trend. Consumers have generalized isoelastic utility functions with 
annual time discount factors 0.95 (Lucas's number), relative risk aversion coefficients of 1 , and intertemporal substitution elasticities of 0.25 . $^{31}$

The numbers in table 4 are based on a greater reduction in consumption variability than would be feasible in reality. But they suggest that for many developing countries, mechanisms to reduce consumption risk--such as increased access to world financial markets or Shiller's (1993) proposed market in perpetual claims to national GDPs--could yield a dramatic payoff.

\section{The allocation of global investment}

A well-functioning world capital market should direct investment toward its most productive global uses. Economic efficiency requires that the expected value of investment in any location be the same. The most direct approach to evaluating efficiency would compare capital's rate of return in different countries, but it is difficult to find internationally comparable measures of the ex ante return to capital. This section therefore focuses on two indirect approaches. One indirect approach argues that capital should flow from countries where it is relatively abundant to countries where it is relatively scarce. A second indirect approach is based on an examination of countries' saving and investment patterns.

${ }^{31}$ For details on the formulas used see Obstfeld (forthcoming, b). The assumptions on time preference, risk aversion, and intertemporal substitutability are conservative; more realistic assumptions would raise the costs in table 4. 
Does capital flow to capital-poor countries?

In the simplest one-sector growth models, capital mobility ensures that countries sharing a common technology will converge to identical capital-output ratios. Figure 8 shows that for the two years 1973 and 1987, this equality was not even approximately true among the six OECD countries for which Maddison (1991) has constructed comparable capital-stock data. Moreover, there is very little tendency for capital-output ratios to converge between 1973 and 1987. A cross-sectional regression of the change in the log capital-output ratio $K / Y$ on the initial log capital-output ratio yields a small and insignificant slope coefficient:

$$
{\log (K / Y)_{1987}-\log (K / Y)_{1973}}_{(0.13)} \underset{(0.16}{0.47)}-\underset{(0.07}{0.06(K / Y)_{1973} ;} R^{2}=0.01
$$

Are such persistent international differences in capital-output ratios prima facie evidence of capital market failure? Suppose aggregate output in a country is produced via the (possibly country-specific) Cobb-Douglas production function of capital $K$ and $N$ other productive factors $L_{j}$

(3) $Y=\left(\Theta_{k} K\right)^{\alpha} \prod_{j=1}^{N}\left(\Theta_{j} L_{j}\right)^{\alpha}$.

The marginal product of capital in this economy is 


$$
M P K=\frac{\alpha}{K / Y}
$$

If countries' outputs are given by Cobb-Douglas production functions of form (3), then even when those production functions differ in factor productivities (the $\theta s$ ) and in the array of noncapital inputs, their $M P K$ ratio equals the inverse of their relative capital-output ratio provided only that they share a common value of $\alpha$, capital's share in GDP.

This simple result has strong implications. Figure 8 suggests, for example, that as of $1987, K / Y$ was around 1.9 for Japan but under 1.3 for the United States. With a common $\alpha=1 / 3$, the value suggested by Mankiw, Romer, and Weil (1992), the marginal product of capital would have been 17.4 percent in Japan, much below its value of more than 25.3 percent in the United States. Under free capital mobility investment should have been higher in the U.S. than in Japan; in reality the reverse was true. If one applies this type of argument to compare returns to capital in developed and developing countries (as do King and Rebelo 1993 and Lucas 1990), the discrepancies are even greater.

A pitfall in the preceding reasoning is the assumption of an internationally common aggregate production function of form (3). If there are multiple production activities with different capital requirements, aggregate capital-output ratios can differ widely between economies that pay the same factor rewards. Furthermore, factors could be more substitutable in some activities (at least in the long run) than the Cobb-Douglas form assumes. For example, capital substitutes for land in some Japanese production activities that are carried out in the U.S. with 
more land and less capital. The evidence that $\alpha$ is a universal constant is weak. Expected changes in relative prices will influence expected returns. Finally, uncertainty is being ignored. If the productivity coefficients $\theta$ are stochastic and imperfectly correlated across countries, we wouldn't expect to observe the same $K / Y$ ratio everywhere: more capital should be placed in countries where the payoff to investment is most highly correlated with the marginal utility of world consumption. Bardhan (1993) explores several models in which big international wage discrepancies coexist with small differences in international returns to capital.

Examination of countries' aggregate capital-output ratios cannot, in itself, be informative about opportunities for efficiency-enhancing international investment flows. A more convincing, albeit painstaking, method is to evaluate sectoral rates of return directly, as in Minhas's (1963) famous study. Little recent work along these lines is readily available.

The Feldstein-Horioka approach

As section 1 above described, Feldstein and Horioka (1980) and Feldstein (1983) proposed as a barometer of capital mobility the size of the association between economies' savings rates and their investment rates. They reasoned that in a world of capital mobility, each country's savings are free to flow to their most productive uses anywhere in the world--there is no reason for an increase in national saving necessarily to augment the source country's domestic capital stock. These papers use regressions of domestic investment rates on national savings rates to 
measure the fraction of an exogenous increase in national savings that will remain at home, the "savings retention coefficient" as Feldstein and Bacchetta (1991) call it. The saving-investment puzzle is to explain why this coefficient appears to be high, even in recent data, despite the high international capital mobility suggested by the evidence on interest-rate links reviewed in section 2 .

Informed policy decisions may depend on whether the saving-investment puzzle really is explained by low capital mobility, or by factors that simultaneously drive both saving and investment. For example, under perfect capital mobility an increase in the government deficit of a small economy need not crowd out domestic investment, even if consumers do not behave according to the Ricardian equivalence proposition: instead, foreign savings are available in perfectly elastic supply to finance additional national borrowing. Feldstein and his collaborators, in contrast, have interpreted their saving-investment regressions as implying that any fall in national saving will, over the long run, cause a commensurate fall in domestic investment, as in a closed economy.

The Feldstein-Horioka approach raises two distinct questions. First, is a close association between saving and investment in fact evidence of low international capital mobility, as argued in the initial papers by Feldstein and Horioka? Second, do regressions of investment on saving actually measure the investment effect of an exogenous change in the saving rate, for example, one caused by fiscal policy? These two questions are inseparably linked: before the investment effect of a change in national saving can be predicted, the precise mechanism 
underlying the estimated saving-investment association must be understood. Because of space limitations, however, this survey will focus on the first question, the relevance of the statistical saving-investment relationship for assessing international capital mobility. 32

Cross-sectional versus time-series estimation In answering this question it is helpful to distinguish between two possible econometric approaches to the estimation of saving-investment relationships.

Feldstein and Horioka (1980) implemented a cross-sectional estimation strategy. In this approach each observation consists of a country $j$ 's average investment and saving rates over a given time period; the estimated regression equation based on a cross-sectional sample of $N$ countries is

(4) $(I / Y)_{j}=\alpha^{C S}+\beta^{C S}(S / Y)_{j}+u_{j}$

where $(I / Y)_{j}$ is country $j$ 's average nominal investment rate out of nominal GNP or GDP over the chosen time period, $(S / Y)_{j}$ is its average saving rate over the same period, and $u_{j}$ is a random disturbance.

A second estimation strategy is based on time-series data. In this approach each observation consists of a given country's investment and saving rates over some time period $t$. The estimated regression equation based on a time-series sample for a single country is

$$
(I / Y)_{t}=\alpha^{\mathrm{TS}}+\beta^{\mathrm{TS}}(S / Y)_{t}+u_{t}
$$

32

Obstfeld (1991) analyzes econometric pitfalls of using saving-investment regressions to predict the effects of exogenous shifts in saving. 
(or the corresponding equation in first differences). 33

In a world of completely immobile capital, the error terms in (4) and (5) represent measurement error and both estimation strategies yield estimated slope coefficients near 1. More generally, however, the two estimation strategies could yield quite different slope coefficients, even when all countries are integrated into world capital markets to a similar degree, because $\beta^{\text {CS }}$ in (4) and $\beta^{\text {TS }}$ in (5) measure very different things.

Suppose, for example, that in the sample of $N$ countries mean saving rates have a high positive cross-sectional association with mean investment rates, but that for each country, deviations of saving rates from the time-series mean are uncorrelated with deviations of investment rates from the time-series mean. Suppose also that the cross-sectional observations are country averages over $T$ periods. Then the ordinary least squares (OLS) estimate $\hat{\beta}^{\text {cS }}$ will be high if $T$ and $N$ are sufficiently large, but $\hat{\beta}^{\text {TS }}$ will be near zero for each country. If instead mean saving rates and investment rates have a zero cross-sectional correlation, but for each country, deviations from its mean saving and investment rates tend to be close, $\hat{\beta}^{\text {cS }}$ will be near zero for $T$ and $N$ sufficiently large but the estimates $\hat{\beta}^{\text {TS }}$ will be high.

The cross-sectional estimation strategy attempts to capture the relationship between long-run saving and investment rates; for this

\footnotetext{
${ }^{33}$ Feldstein (1983) reports panel estimates that combine the cross-section and time-series strategies by assuming that $\beta^{\text {CS }}$ and $\beta^{\text {TS }}$ are equal.
} 
strategy to succeed, each country's saving and investment rates must be averaged over a sufficient interval to eliminate the influence of short-run fluctuations around long-run means. The time-series estimation strategy is meant to uncover the short-run relationship between national saving and domestic investment. Both long-run and short-run relationships are pertinent to an assessment of capital mobility. Explanations of the time-series relationship between saving and investment will not, however, throw much light on the cross-sectional relationship unless the time period chosen for cross-sectional estimates is so brief that transitory shocks to saving and investment swamp underlying long-run patterns. Conversely, explanations of true long-run patterns may have little power to explain short-run comovements.

Results of cross-sectional estimation Feldstein and Horioka (1980) estimated (4) for a sample of 16 OECD countries, averaging annual data over subperiods of $1960-74 .^{34}$ Data on gross saving and investment rates ${ }^{35}$ averaged over the entire $1960-74$ period led to a representative OLS result:

$$
\begin{aligned}
(I / Y)_{j}= & 0.035+0.887(S / Y)_{j} \\
& (0.018)(0.074)
\end{aligned}
$$

Feldstein and Bacchetta (1991) provide an update; a typical estimate of

34

Their country sample was Australia, Austria, Belgium, Canada, Denmark, Finland, Germany, Greece, Ireland, Italy, Japan, the Netherlands, New Zealand, Sweden, the U.K., and the U.S. 35 Gross, rather than net rates, are more appropriate for this regression. A regression in net rates imposes the assumption that all replacement investment is financed by domestic savings. 
$\beta^{\text {CS }}$ based on a sample of 23 OECD countries over the more recent period 1974-86 is 0.868 (with a standard error of 0.145 ), a result quite close to the original findings. ${ }^{36}$ This regression presents a much starker puzzle about the international capital market than those based on 1960-74 data because it is generally believed that the world capital market, while relatively shallow and segmented prior to the early 1970s, has become less regulated and expanded vigorously since then. ${ }^{37}$ Notwithstanding this evolution, the Feldstein-Bacchetta findings still imply that a one percent increase in the national saving rate remains cross-sectionally associated with a nearly equal increase in the domestic investment rate.

A further update is provided in table 5 , which presents the result of estimating (4) for 22 OECD countries over subperiods of 1974-90. 38 Saving and investment rates are gross nominal flows divided by nominal GDP or GNP.

The point estimates for $\beta^{\mathrm{CS}}$ in table 5 are lower than those that Feldstein and Horioka (1980) report and somewhat lower, on the whole, than those that Feldstein and Bacchetta (1991) report. The $R^{2}$ statistics are also below the ones in Feldstein and Horioka (1980). Figure 9 shows a scatter plot for the 1981-90 data, together with the fitted regression line.

${ }^{36}$ The countries are those listed in the previous footnote plus France, Iceland, Norway, Portugal, Spain, Switzerland, and Turkey.

${ }^{37}$ See Marston (1993b) for evidence on the 1960s.

${ }^{38}$ The countries are the Feldstein-Bacchetta sample less Turkey, which can be classified as a developing country. Luxembourg traditionally is omitted from this sample; it is such an extreme outlier that its addition reduces the cross-sectional regression coefficient to insignificance. 
The results are suggestive of a decade-to-decade downward trend in $\beta^{\mathrm{CS}}$ : the estimated coefficient over $1974-80,0.867$, has dropped to 0.636 by 1981-90. Such a trend, even if established, would be difficult to interpret unambiguously. For example, the $1986-90$ estimate of $\beta^{\text {CS }}$ is higher than that for 1981-85, yet one would not take this as evidence of a decreasing degree of international capital mobility. The coefficient differences are not significant in statistical terms.

The basic finding is that the positive cross-sectional association between $\mathrm{OECD}$ saving and investment rates is economically and statistically significant, although far from perfect and possibly declining over time. Although the cross-sectional results are less striking than those for 1960-74, they may present more of a puzzle given the present level of industrial-country residents' participation in international capital markets. 39

Results for a wider sample including developing countries are not reported, because there is less of a saving-investment puzzle as far as those countries are concerned. Most of these countries even now control capital flows and in some periods have faced binding external credit constraints. Notwithstanding these tangible impediments to capital flow, over the period from 1960 to the early 1980s (when the debt crisis began), the cross-sectional association of saving and investment rates is often found to be lower for the developing countries than for the OECD countries. 40

${ }^{39}$ For documentation of this activity see, once again, Goldstein et al. (1993).

${ }^{40}$ See Fieleke (1982), Dooley, Frankel, and Mathieson (1987), and Summers 
Results of time-series estimation Table 6 examines the time-series properties of annual saving and investment rates over 1974-90 for the 22 countries that made up the cross-sectional sample, plus Luxembourg. "Levels" estimates of $\beta^{\text {TS }}$ comes from OLS estimation of (5) (with a time trend included in the regression). "Differences" estimates come from the regression

$$
\Delta(I / Y)_{t}=\alpha^{\mathrm{TS}}+\beta^{\mathrm{TS}} \Delta(S / Y)_{t}+\Delta u_{t}
$$

Table 7 reports the corresponding simple correlation coefficients between linearly detrended and differenced saving and investment rates.

There is a wide dispersion of outcomes, a reflection not only of different degrees of financial openness, but also of different country sizes and the different shocks that have buffetted these diverse economies. For most countries the saving and investment time series are positively related, and typically the relationship is strong. Australia, New Zealand, and Portugal all show positive time-series saving-investment associations despite having run sizable current-acount deficits over parts of the sample period. (Portugal's 1982 deficit was 13.5 percent of GDP.) Norway, which did the same, shows a strongly negative relationship. These findings underscore the point that annual time-series correlations contain little information about the relationship between saving and investment over long periods. 41

(1988).

${ }^{41}$ Observe that choice of detrending method can make a big difference (for 
Even under perfect capital mobility, positive regression coefficients such as those reported in the table are not hard to explain. If labor is internationally immobile, for example, positive shocks to investment productivity can cause both investment and saving to rise (Obstfeld 1986; Finn 1990; Tesar 1991; Ghosh, forthcoming). If the usual outcome of such a shock is a current-account deficit, and if productivity shocks are the dominant form of disturbance, then it would not be surprising to find an estimate of $\beta^{T S}$ above 1, a result found for several countries in table 6 but difficult to explain if capital is internationally immobile. A positive time-series correlation between saving and investment is reinforced if global as well as local shocks to investment and saving are important (as Glick and Rogoff, 1993, find). ${ }^{42}$

Unlike the time series results, which can be rationalized in several plausible ways, the cross-sectional finding that countries with higher long-term saving rates also have higher long-term investment rates is more difficult to explain in a world of capital mobility. The balance of this section therefore focuses on alternative interpretations of the cross-sectional saving-investment pattern as it persisted through the 1980 s.

Explanations for the cross-sectional saving-investment relationship Many researchers have taken the high estimates of $\beta^{\mathrm{CS}}$ in (4) as

example, the United Kingdom).

42 Baxter and Crucini (1993), Cardia (1992), Mendoza (1991a, 1991b), and Stockman and Tesar (1990) explore simulation models with perfect capital mobility in which high time-series correlations between saving and investment arise. 
evidence that national savings for the most part still are retained at home and are not channeled toward their most efficient global uses by the world capital market. Others have tried to approach the saving-investment puzzle by identifying economic forces that underlie both saving and investment and cause long-term averages of these two variables to move together. A wide variety of mechanisms has been proposed.

Demographic factors Characteristics of a nation's labor force can simultaneously affect national saving and the profitability of domestic investment. Labor-force growth provides one example: higher growth can raise national saving by increasing the ratio of young savers to old dissavers; at the same time higher growth raises the investment needed to keep the labor force equipped with capital (Black 1982; Obstfeld 1986).

Summers (1988) and Feldstein and Bacchetta (1991) dismiss the hypothesis that labor-force growth is "the" cause of the cross-sectional saving-investment relationship. They show that the addition of growth variables to the cross-sectional regression does not reduce the apparent influence of saving on investment. Notwithstanding these regressions, it remains quite plausible that labor-force developments are a part of the story, more important in some countries than in others. Tesar (1991) presents some evidence along these lines, showing that the fraction of the population aged between 15 and 64 is positively related to both saving and investment rates. The question deserves more detailed study.

Other potential links between household allocation decisions and investment remain to be investigated. For example, are there systematic links among fertility rates, saving, expenditures on schooling, and the profitability of domestic investment? 
Real interest rates Even if capital is perfectly mobile and uncovered interest parity holds true, national real interest rates need not be equal. Frankel $(1986,1993)$ claims that this point resolves the Feldstein-Horioka puzzle. The puzzle arises, he argues, because increases in national saving depress the local real interest rate, spurring investment and inducing a statistical correlation between saving and investment rates.

While this mechanism may help us understand time-series correlations between saving and investment rates, its bearing on the longer-run cross-sectional patterns is less obvious. Under the conditions listed in the last paragraph, the real interest differential between two countries equals the expected percentage change in their currencies' real exchange rate. If real interest effects are to explain the cross-sectional regression results, countries with high saving and investment rates must have low real interest rates and so their currencies must be continually appreciating in real terms against foreign currencies.

Cardia (1992) describes a simulation model which is based on Frankel's suggested mechanism, but which nonetheless may have some explanatory power for the cross-sectional Feldstein-Horioka pattern. In her model, adjustment to shocks can be drawn out over decades because of capital-installation costs and an overlapping-generations population structure. Although Cardia does not report cross-sectional simulations, the long-lived effects of the disturbances she considers probably would contribute to a strong cross- sectional association between long savingand investment-rate averages.

As Balassa's (1964) work implies, models with different sectoral 
productivity growth rates can exhibit permanently trending real exchange rates. This suggests another potential mechanism causing high-saving, high-investment countries also to be countries with low real interest rates. Imagine a small-open economy producing traded and nontraded goods using capital (which is internationally mobile) and labor (which is not). Assume that initially all countries are identical. Consider the effect of a permanent increase in traded-goods productivity growth in one economy.

The currency of this economy will begin to appreciate in real terms at a higher rate, its real interest rate will fall, and its investment rate will rise. Saving, which depends on the real interest rate, also will change. If the average domestic intertemporal substitution elasticity is below 1 (as several empirical studies suggest), the fall in the real interest rate will cause saving to rise (and the rate of total real expenditure growth to fall). Saving and investment thus will tend to show a positive cross-sectional correlation, seemingly driven by cross-country real interest rate differences but really driven by differences in traded-goods productivity growth. 43

No one has yet established a robust cross-sectional relationship among saving, investment, the real interest rate, and the real exchange rate's expected path. Mechanisms such as the one described thus remain speculative.

${ }^{43}$ In general, when an economy has several sectors of differing capital intensity, some of which produce nontraded goods, there is no longer a presumption that the economy's consumption side and its production side (including investment) can be analyzed separately, even under capital mobility. This point is made through various examples by Murphy (1986), Engel and Kletzer (1989), and Wong (1990). 
Hysteresis of factor supplies Results presented above (figure 8) show that OECD countries are characterized by wide and persistent differences in capital-output ratios. This pattern suggests another possible explanation for the saving-investment puzzle.

European countries entered the postwar era burdened by external payments controls and limited access to foreign resources. For some time, therefore, countries had to finance most of their capital accumulation through domestic savings. High-saving countries accumulated large capital stocks and specialized in capital-intensive industries, while low-saving countries ended up producing a more labor-intensive product mix.

The subsequent liberalization of capital movements need not have disturbed this production pattern greatly. In the presence of labor-force growth, however, high-capital countries required high investment rates to maintain their established industries, while low-capital countries could get by with lower investment rates. Since the high-capital countries also were those with high saving rates, a high cross-sectional correspondence between saving and investment rates was the result. On this view, the historical accident of capital immobility during the first part of the postwar period had an effect on the distribution of national investment rates that persisted even after capital mobility returned.

If the preceding interpretation is valid, countries with higher saving and investment rates should have higher shares of capital income in GDP. Mankiw, Romer, and Weil (1992) argue, however, that this is not the case and that in fact there is little international variation in 
capital's GDP share. ${ }^{44}$ Their argument, based on limited data from the 1960s and 1970s, contradicts Kaldor's (1961) fifth "stylized fact" of economic growth: "A high correlation between the share of profits in income and the share of investment in output" (p. 178). More research on this point would be useful.

Corporate financing frictions The need for firms facing imperfect domestic capital markets to finance investment out of corporate savings has been suggested as another explanation of the Feldstein-Horioka puzzle. But is a tight link between corporate saving and investment enough to produce a tight link between national saving and investment? A dollar rise in corporate saving may raise domestic investment if firms are borrowing-constrained, but it will raise national saving only if shareholders fail to pierce the corporate veil and adjust their own total saving downward by a dollar. The largest corporations, moreover, do not face binding finance constraints.

A related hypothesis concerns the possibility that domestic and foreign residents value domestic equities differently, as generally is the case in the absence of efficient consumption risk-sharing among countries. (Dooley, Frankel, and Mathieson, 1987, examine a polar case in which claims to domestic physical capital are nontradable.) In this situation, domestic saving and investment could be correlated, even for a small country, despite perfect international arbitrage in bonds. Can this type of equity-market segmentation help explain the cross-sectional

${ }^{44}$ This pattern would be consistent with a world in which national outputs are produced according to (3) (with $\alpha$ the same in all countries) and capital is internationally immobile. 
saving-investment results? One obvious approach would be look for a negative cross-sectional correlation between the cost of capital and the saving rate in industrial countries. 45

The general point is that strict domestic segmentation of financial markets could generate a saving-investment relationship.

Country-by-country empirical documentation for this mechanism has not yet been produced.

Government policies Systematic current-account targeting by governments would, if successful, tend to produce a strong cross-sectional saving investment association, even with high capital mobility (Fieleke 1982; Summers 1988). Fiscal and monetary policy, as well as capital controls, have all been used to limit the sizes of current-account imbalances. There is some evidence that government policies in a number of countries have aimed to curtail external imbalances (Artis and Bayoumi 1989), but it is difficult to judge how well these policies succeeded. It is also possible that government policies aimed at domestic stabilization or international reserve management have effects similar to current-account targeting.

If capital mobility is high, however, there may be less reason for a government to target the current account than if capital mobility is low: economy-wide credit constraints that private agents may fail to internalize are less stringent. On the other hand, governments trying to fix currency exchange rates in the face of speculative pressure may well

${ }^{45}$ There is some evidence of such a relationship in the past; see McCauley and Zimmer (1989). However, it is hard to disentangle the effect of saving from the effect of tax provisions that simultaneously affect saving and the cost of capital. 
take actions that limit current account imbalances.

The economy's intertemporal budget constraint An open economy faces an intertemporal budget constraint relating the difference between its saving and investment--the current account--to the change in its net external assets. Under some economic conditions this constraint alone implies that saving and investment ratios averaged over sufficiently long periods must be close despite capital mobility. ${ }^{46}$

To appreciate this point, let $A_{t}$ denote a given country's nominal net foreign assets at the end of period $t$ and recall the current-account identity's implication that $A_{t}-A_{t-1}=S_{t}-I_{t}{ }^{47}$ Suppose that the data are average saving and investment rates over $T$ periods. Let $a_{t}=A_{t} / Y_{t}$ be the ratio of external assets to income and $g_{t}=\left(Y_{t}-Y_{t-1}\right) / Y_{t}$ the growth rate of nominal income. Then the current-account identity implies that the difference between the averaged saving and investment rates is 48

(6) $\frac{1}{T} \sum_{t=1}^{T} \frac{S_{t}-I_{t}}{Y_{t}}=\frac{1}{T} \sum_{t=1}^{T} \frac{A_{t}-A_{t-1}}{Y_{t}}$

$$
=\frac{1}{T}\left[a_{T}+\left(1-\frac{Y_{T-1}}{Y_{T}}\right) a_{T-1}+\ldots-\left(\frac{Y_{0}}{Y_{1}}\right) a_{0}\right]
$$

${ }^{46}$ See Obstfeld (1986, p. 73), Sinn (1992) and Vikøren (1991).

${ }^{47}$ This relation will not hold exactly in the data because saving as measured by national income and product accounts does not include capital gains or losses on foreign assets (see Obstfeld 1986). 48

The income growth rates below are nominal rather than real rates because the national income and product account concept of saving does not correct income for the inflationary erosion of nominal assets' real values. 


$$
=\frac{1}{T}\left(a_{T}-a_{0}+g_{T} a_{T-1}+\ldots+g_{2} a_{1}+g_{1} a_{0}\right) .
$$

In principle, the foregoing identity alone places no constraints on the average difference between saving and investment rates. Suppose, however, that there is a steady-state ratio of net foreign assets to income from which the economy does not greatly diverge between the start and end of the sample period. Then if nominal income growth is moderate, (6) implies that the averaged difference between saving and investment rates may well be small. Mature economies may have attained a stationary distribution of the foreign assets/GNP ratio; the intertemporal trade gains that arise between mature economies generally will be transitory and their distribution symmetical. ${ }^{49}$ This conjecture may help explain why even in the late 1980s a fairly high cross-sectional saving-investment relation persisted for the industrial countries. The conjecture also explains why, before the debt crisis of the 1980s, developing countries displayed lower cross-sectional saving-investment correlations than developed. Developing countries with significant unexploited investment opportunities have external debts well below their steady-state levels. This perspective suggests that ultimately, the cross-sectional saving-investment correlation within a group of countries

${ }^{49}$ An exception is Norway, which borrowed abroad so heavily during the 1970 s to develop its oil production that by 1978 its foreign debt/GDP ratio stood near 60 percent (Vikøren 1991). Even Norway repaid this debt quickly: by 1985 the country's net foreign debt stood at around 12 percent of GDP, its 1970 level. The United States current account deficit, driven by goverment deficits and demographic shifts, is another exception. 
with open capital markets depends on the extent of each one's long-term intertemporal trade gains with other countries. Attempts to assess these gains (as in Ghosh, forthcoming, and Glick and Rogoff 1993) are critical for understanding how puzzling the saving-investment puzzle really is.

Comparisons with the gold standard and with regional data

An indirect way to judge whether the Feldstein-Horioka puzzle reflects true capital immobility or some subset of the alternative factors listed above is to examine the strength of the cross-sectional saving-investment association in settings of presumed capital mobility. Data from the gold-standard period and regional data have both been used for this purpose.

The saving-investment relation under the gold standard Table 8 reports results for three data samples. The first consists of Australia, Canada, Denmark, France, Germany, Italy, Norway, Sweden, the U.K., and the U.S. with data averaged over 1880-1913. The second sample adds Japan, using data averaged over 1885-99 and 1900-13. The third sample, based on 1926-38 data, subtracts France but adds Finland, which gained independence from Russia in 1917. I first discuss the pre-1914 results, which fall under the classical gold standard. 50

Over 1880-1913, the estimated regression coefficient $\hat{\beta}^{\mathrm{cs}}$ is almost significant (with a one-tailed test) and not too different from the estimates in table 5 based on data from the 1980s. (The $R^{2}$ is, however,

${ }^{50}$ For details on data construction, see Jones and Obstfeld (1994). 
much lower in table 8 ). Over $1885-99$ the estimate $\beta^{\text {cS }}$ is the same but significant. For the 1900-13 period (with data pictured in figure 10), the coefficient rises to 0.77 , but loses significance. ${ }^{51}$

To the extent that the classical gold standard was a period of high international financial integration, the pre-1914 findings in table 8 and figure 10 suggest that the recent long-run behavior of saving and investment rates is not inconsistent with substantial capital mobility.

True, the dispersion of saving and investment rates during the gold standard is greater than among industrial countries over the 1980s; and among the largest economies we now see nothing like the surpluses the U.K. persistently ran. Three factors should be considered, however, in assessing capital mobility under the classical gold standard and comparing it with curent conditions. First, as Nurkse (1954) emphasized, international capital movements were abetted by complementary large-scale labor movements from Europe into regions of recent (white) settlement. Nothing like the level of migration seen then has occurred in the postwar era. 52 Second, the inclusion of Australia and Canada means that devlopingand developed-country data are being pooled, a procedure that would loosen the saving-investment association in modern data. Finally, Britain's close cultural and political ties with some borrowers certainly facilitated its large-scale foreign lending. As is evident from figure

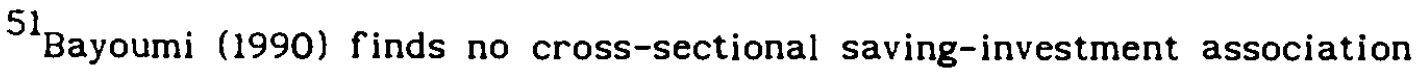
for a smaller eight-country sample over any subperiod of 1880-1913. Eichengreen (1990) amends Bayoumi's data and adds the United States. The results in table 8 are very similar to Eichengreen's, despite my use of different data for some countries and an expanded set of countries. ${ }^{52}$ See Razin and Sadka (1993) for a recent discussion of international labor mobility. 
10. Canada and the U.K. are behind the poor fit of the 1900-13 regression.

Table 8 also reports a regression for the interwar period following the (short-lived) reinstatement of the international gold-standard, 1926-38; the data are displayed in figure 11. The results stand in the sharpest possible contrast to those for the classical gold standard, and show a stronger saving-investment association even than the 1960-74 Feldstein-Horioka results. Eichengreen (1990) discusses possible reasons for this contrast, which are complex but seem related to a genuine post-World WarI decline in capital mobility. One factor behind this decline was the rise of the political Left. This development made international investors less secure in their property rights than they were before 1914. It also focused the attention of policymakers on domestic economic problems at the expense of laissez-faire principles of international economic relations.

During the classical gold-standard era governments practiced less pervasive management of their economies than afterward. Do the results of this section therefore show that the hypothesis of current-account targeting is not needed to explain the current cross-sectional saving-investment relation? Not at all. Even under the gold standard, some governments may have curtailed current-account imbalances as a side effect of actions taken to maintain gold convertibility, or in pursuit of foreign policy aims.

Regional saving-investment links The use of regional saving and investment data is a potentially fruitful way to throw light on the 
saving-investment puzzle. ${ }^{53}$ Bayoumi and Rose (forthcoming) construct saving and investment data for 11 British regions over 1971-85; they find no significant positive cross-sectional relationship between saving and investment rates. Bayoumi and Sterne (1993) find a similar result for Canadian provinces. Sinn (1992), who looks at both 1953 and 1957 data for the 48 U.S. states and Alaska, finds a negative cross-sectional relationship between saving and investment rates. Data over 1975-88 on average saving and investment rates for the 45 Japanese prefectures listed in table 3 are graphed in figure 12. Again, no positive relationship is apparent.

The data used in these calculations aren't always ideal. For example, Bayoumi and Rose have data for only part of regional expenditure and investment. More seriously, Bayoumi and his coauthors define saving as regional GDP less a regional consumption measure, not as GNP less that measure. Thus, these measures of saving fail to include in income not only net interest and dividend payments from outside the region, but also net transfers from the domestic central government and others. The much greater dispersion of saving than investment rates in figure 12 raises suspicions that measurement errors are a problem in the Japanese saving data shown there, despite their definition as prefecture GNP less consumption.

There are, moreover, differences between regions and countries that

${ }^{53}$ Murphy (1984) applied a similar idea to the 143 largest industrial corporations from the 1981 Fortune 500. He found a significant cross-sectional relation between corporate saving and investment. It would be interesting to know if this relationship has held up in view of financial-market developments since the early 1980 s. 
might weaken the saving-investment link. The comparative ease with which labor can migrate between regions could alter the response of regional saving and investment to disturbances. (This is especially possible in Japan, where commuting between prefectures is significant.) Furthermore, regions within countries tend to be more specialized in their production activities than are countries themselves. Thus, some of the shocks that can make national saving and domestic investment move together may not induce similar comovements in regional saving and investment.

The strength of factors such as these is unknown at present. Until more work is done and better data assembled, the regional saving-investment regressions provide the most persuasive evidence that national boundaries or policies placed limits on industrial-country current-account imbalances through the 1980 s.

Since regional current accounts are not objects of government policy, the regional results leave current-account targeting as a prime suspect behind the cross-sectional saving-relationship that has persisted in international data. The results are also consistent with the view that capital is still not as mobile between as within countries.

\section{Conclusion}

The main conundrum in thinking about international capital mobility is to reconcile measures of mobility that superficially contradict each other. How can one square the generally smooth international interest-rate arbitage documented in section 2 with the low international consumption correlations and home portfolio bias discussed in section 3 or the still-sizable cross-sectional coherence between saving and 
investment documented in section $4 ?$ In this paper I have reviewed a number of economic models and data limitations that potentially can contribute to a reconciliation. Despite years of research, however, economists still have not reached the semblance of a consensus on which factors are most relevant. Much work remains to be done; hopefully, the rapid evolution of world capital markets, if not braked by renewed regulation, will furnish more clues as well as data.

After such a a lengthy and arduous trek through the literature, I owe the reader more, however, than just a plea for more of the same. So here are my tentative conclusions.

How mobile is capital in the world economy? As far as industrial countries are concerned, capital mobility appears substantial when judged by the measure of past experience, such as the classical gold-standard era. I have not presented as thorough a review of developing country experience in this paper, because that experience is diverse and the market access of many developing countries is currently in flux. It is clear, however, that most of the developing world still stands outside the nexus of industrial-country financial markets.

Capital mobility appears noticeably lower between industrial economies than it is within them, although intereconomy capital mobility certainly has increased over time. The threat of government intervention in coss-border capital movements has not disappeared. (Indeed, in the wake of the August 1993 ERM collapse, European Commission President Jacques Delors signaled his support of concerted EC measures to limit 
capital mobility. ${ }^{54}$ ) Financial flows apparently are less extensive between than within countries. International portfolio diversification appears inexplicably limited for some major countries. And long-run saving and investment rates remain positively associated in international cross sections to an extent greater than is true in the (usually imperfect) regional data that are available. This last phenomenon could reflect central government policies that have the effect of limiting national current-account imbalances.

It is doubtful that capital will ever be as mobile between nations as it can be within them. The mere existence of national governments sovereign within their borders means that no investor can think about domestic and foreign assets in quite the same way. What is at issue, then, is the extent to which actual conditions approximate free capital mobility. Among industrial countries the approximation has become better and better in recent years, but it still has some ways to go.

${ }^{54}$ See "Return of Capital Controls Raised by Delors," Financial Times, September 16, 1993, p. 1. 


\section{References}

Altonji, Joseph G., Fumio Hayashi, and Laurence J. Kotlikoff, "Is the Extended Family Altruistically Linked? Direct Tests Using Micro Data," American Economic Review 82 (December 1992), pp. 1177-1198.

Artis, Michael, and Tamim Bayoumi, "Saving, Investment, Financial Integration, and the Balance of Payments," WP/89/102, International Monetary Fund, Research Department, December 1989.

Atkeson, Andrew, and Tamim Bayoumi, "Do Private Capital Markets Insure Regional Risk? Evidence from the United States and Europe," mimeo, University of Chicago and International Monetary Fund, June 1992.

Backus, David K., Patrick J. Kehoe, and Finn E. Kydland, "International Real Business Cycles," Journal of Political Economy 100 (August 192), pp. $745-775$.

Balassa, Bela, "The Purchasing-power Parity Doctrine: A Reappraisal," Journal of Political Economy 72 (December 1964), pp. 584-596.

Bardhan, Pranab, "Disparity in Wages but Not in Returns to Capital between Rich and Poor Countries," Center for International and Development Economics Research, Working Paper C93-017, University of California at Berkeley, July 1993.

Baxter, Marianne, and Mario J. Crucini, "Explaining Saving/Investment Correlations," American Economic Review 83 (June 1993), pp. 416-436.

Baxter, Marianne, and Urban J. Jermann, "The International Diversification Puzzle is Worse Than You Think," Rochester Center for Economic Research Working Paper 350, May 1993.

Bayoumi, Tamim, "Saving-Investment Correlations," International Monetary Fund Staff Papers 37 (June 1990), pp. 360-387.

Bayoumi, Tamim, and Gabriel Sterne, "Regional Trading Blocs, Mobile Capital, and Exchange Rate Coordination," mimeo, Bank of England, January 1993.

Bayoumi, Tamim A., and Andrew K. Rose, "Domestic Saving and Intra-National Capital Flows," European Economic Review, forthcoming.

Black, Stanley W., "Discussion," in Saving and Government Policy, Conference Series 25, Boston, Federal Reserve Bank of Boston, 1982, pp. 158-161.

Brainard, William C., and James Tobin, "On the Internationalization of Portfolios," Oxford Economic Papers 44 (April 1992), pp. 533-565. 
Calvo, Guillermo A., Leonardo Leiderman, and Carmen M. Reinhart, "Capital Inflows and Real Exchange Rate Appreciation in Latin America: The Role of External Factors," WP/92/62, International Monetary Fund, Research Department, August 1992.

Campbell, John Y., and N. Gregory Mankiw, "The Response of Consumption to Income: A Cross-Country Investigation," European Economic Review 35 (May 1991), pp. 723-767.

Canova, Fabio, and Morten Overgaard Ravn, "International Consumption Risk Sharing," mimeo, European University Institute, March 1993.

Cardia, Emanuela, "Crowding Out in Open Economies: Results from a Simulation Study," Canadian Journal of Economics 25 (August 1992), pp. 708-728.

Carroll, Christopher D., and Lawrence H. Summers, "Consumption Growth Parallels Income Growth: Some New Evidence," in B. Douglas Bernheim and John B. Shoven, eds., National Saving and Economic Performance, Chicago, University of Chicago Press, 1991, pp. 305-343.

Cole, Harold L., "Financial Structure and International Trade," International Economic Review 29 (May 1988), pp. 237-259.

Cole, Harold L., and Maurice Obstfeld, "Commodity Trade and International Risk Sharing? How Much do Financial Markets Matter?" Journal of Monetary Economics 28 (August 1991), pp. 3-24.

Cochrane, John H., "A Simple Test of Consumption Insurance," Journal of Political Economy 99 (October 1991), pp. 957-76.

Committee of Governors of the Central Banks of the Member States of the European Economic Community, Annual Report 1992, April 1993.

Crucini, Mario J., "International Risk Sharing: A Simple Comparative Test," mimeo, Ohio State University, August 1992.

Deaton, Angus, Understanding Consumption, Oxford: Clarendon Press, 1992.

Dekle, Robert, "Saving-Investment Correlations and Capital Mobility: On the Evidence from Japanese Regional Data," mimeo, Boston University, October 1993.

Deutsche Bundesbank, "The Trend in Germany's External Assets and Investment Income," Monthly Report of the Deutsche Bundesbank 45 (January 1993), pp. 43-66.

Devereux, Michael B., Allan W. Gregory, and Gregor W. Smith, "Realistic Cross-Country Consumption Correlations in a Two-Country, Equilibrium, Business-Cycle Model," Journal of International Money and Finance II (February 1992), pp. 3-16. 
Dooley, Michael, Jeffrey Frankel, and Donald J. Mathieson, "International Capital Mobility: What Do Saving-Investment Correlations Tell Us?" International Monetary Fund Staff Papers 34 (September 1987), pp. 503-530.

Dumas, Bernard, "Partial-Equilibrium vs General-Equilibrium Models of International Capital Market Equilibrium," in Frederick van der Ploeg, ed., Handbook of International Macroeconomics, Oxford, Basil Blackwell, forthcoming.

Eichengreen, Barry, "Trends and Cycles in Foreign Lending," in Horst Siebert, ed., Capital Flows in the World Economy, Tubingen, J.C.B. Mohr, 1990, pp. 3-28.

Eldor, Rafael, David Pines, and Abba Schwartz, "Home Asset Preference and Productivity Shocks," Journal of International Economics 25 (August 1988), pp. 165-176.

Engel, Charles, and Kenneth Kletzer, "Saving and Investment in an Open Economy with Non-Traded Goods," International Economic Review 30 (November 1989), pp. 735-752.

Feldstein, Martin, "Domestic Saving and International Capital Movements in the Long Run and the Short Run," European Economic Review 21 (March/April 1983), pp. 129-51.

Feldstein, Martin, and Philippe Bacchetta, "National Saving and International Investment," in B. Douglas Bernheim and John B. Shoven, eds., National Saving and Economic Performance, Chicago, University of Chicago Press, 1991.

Feldstein, Martin, and Charles Horioka, "Domestic Saving and International Capital Flows," Economic Journal 90 (June 1980), pp. 314-329.

Fieleke, Norman S., "National Saving and International Investment," in Saving and Government Policy, Conference Series 25, Boston, Federal Reserve Bank of Boston, 1982, pp. 138-157.

Finn, Mary G., "On Savings and Investment Dynamics in a Small Open Economy," Journal of International Economics 29 (August 1990), pp. 1-21.

Frankel, Jeffrey A., "International Capital Mobility and Crowding-Out in the U.S. Economy: Imperfect Integration of Financial Markets or of Goods Markets?" in R. W. Hafer, ed., How Open is the U.S. Economy? Lexington, Mass., Heath, 1986.

- "Quantifying International Capital Mobility in the 1980s," in On Exchange Rates, Cambridge, Mass., MIT Press, 1993. 
French, Kenneth R., and James M. Poterba, "Japanese and U.S. Cross-border Common Stock Investments," Journal of the Japanese and International Economies 4 (December 1990), pp. 476-493.

-. "Investor Diversification and International Equity Markets." American Economic Review 81 (May 1991), pp. 222-226.

Gehrig, Thomas, "An Information Based Explanation of the Domestic Bias in International Equity Investment," Scandinavian Journal of Economics 95 (March 1993), pp. 97-109.

Gertler, Mark, and Kenneth Rogoff, "North-South Lending and Endogenous Domestic Capital-Market Inefficiencies," Journal of Monetary Economics 26 (October 1990), pp. 245-266.

Ghosh, Atish R., "Capital Mobility amongst the Major Industrial Countries: Too Little or Too Much?" Economic Journal, forthcoming.

Giavazzi, Francesco, and Marco Pagano, "Capital Controls and the European Monetary System," in Capital Controls and Foreign Exchange Legislation, Milan, Euromobiliare, June 1985, pp. 19-38.

Glick, Reuven, and Michael Hutchison, "Financial Liberalization in the Pacific Basin: Implications for Real Interest Rate Linkages," Journal of the Japanese and International Economies 4 (March 1990), pp. 36-48.

Glick, Reuven, and Kenneth Rogoff, "Global versus Country-Specific Productivity Shocks and the Current Account," International Finance Discussion Papers 443, Board of Governors of the Federal Reserve System, April 1993.

Goldstein, Morris, David Folkerts-Landau, Peter Garber, Liliana Rojas-Suarez, and Michael Spencer, International Capital Markets, Part I. Exchange Rate Management and International Capital Flows, Washington D.C., International Monetary Fund, April 1993.

Golub, Stephen S., "International Diversification of Social and Private Risk: The U.S. and Japan," mimeo, Swarthmore College, November 1991.

Gordon, Roger H., and Hal R. Varian, "Taxation of Asset Income in the Presence of a World Securities Market," Journal of International Economics 26 (May 1989), pp. 205-226.

Hodrick, Robert J., and Edward C. Prescott, "Post-war U.S. Business Cycles: An Empirical Investigation," mimeo, Carnegie-Mellon University, November 1980.

Jones, Matthew T., and Maurice Obstfeld, "Saving and Investment under the Gold Standard," mimeo, University of California at Berkeley, 1994

Kaldor, Nicholas, "Capital Accumulation and Economic Growth," in F.A. Lutz and D.C Hague, eds., The Theory of Capital, New York, St. Martin's Press, 1961, pp. 177-222. 
King, Robert G., and Sergio T. Rebelo, "Transitional Dynamics and Economic Growth in the Neoclassical Model," American Economic Review 83 (September 1993), pp. 908-931.

Kollmann, Robert, "Consumptions, Real Exchange Rates and the Structure of International Asset Markets," mimeo, Université de Montréal, 1992.

Lewis, Karen K., "What Can Explain the Apparent Lack of International Consumption Risk Sharing?," mimeo, University of Pennsylvania, July 1993.

Lucas, Robert E., Jr., Models of Business Cycles, Oxford, Basil Blackwell, 1987.

- "Why Doesn't Capital Flow from Rich to Poor Countries?" American Economic Review 80 (May 1990), pp. 92-96.

- "On Efficiency and Distribution," Economic Journal 102 (March 1992), pp. 233-247.

McCauley, Robert N., and Steven A. Zimmer, "Explaining International Differences in the Cost of Capital," Federal Reserve Bank of New York Quarterly Review 14 (Summer 1989), pp. 7-28.

Mace, Barbara J., "Full Insurance in the Presence of Aggregate Uncertainty," Journal of Political Economy 99 (October 1991), pp. 928-956.

Maddison, Angus, Dynamic Forces in Capitalist Development, Oxford, Oxford University Press, 1991.

Mankiw, N. Gregory, David Romer, and David N. Weil, "A Contribution to the Empirics of Economic Growth," Quarterly Journal of Economics 107 (May 1992), pp. 407-437.

Mankiw, N. Gregory, and Stephen P. Zeldes, "The Consumption of Stockholders and Nonstockholders," Journal of Financial Economics 29 (1991), pp. 97-112.

Marston Richard C., "Determinants of Short-Term Real Interest Differentials between Japan and the United States," Bank of Japan Monetary and Economic Studies 11 (July 1993a), pp. 33-61.

-, "Interest Differentials under Bretton Woods and the Post-Bretton Woods Float: The Effects of Capital Controls and Exchange Risk," in Michael D. Bordo and Barry Eichengreen, eds., A Retrospective on the Bretton Woods System, Chicago, University of Chicgao Press, 1993b, pp. 515-538.

Mathieson, Donald J., and Liliana Rojas-Suarez, Liberalization of the Capital Account: Experiences and Issues, Occasional Paper 103, Washington, D.C., International Monetary Fund, March 1993. 
Mendoza, Enrique G., "Capital Controls and the Gains from Trade in a Business Cycle Model of a Small Open Economy," International Monetary Fund Staff Papers 38 (September 1991a), pp. 480-505.

_- "Real Business Cycles in a Small Open Economy," American Economic Review 81 (September 1991b), pp. 797-818.

Minhas, Bagicha Singh, An International Comparison of Factor Costs and Factor Use, Amsterdam, North-Holland, 1963.

Murphy, Robert G., "Capital Mobility and the Relationship between Saving and Investment Rates in OECD Countries," Journal of International Money and Finance 3 (December 1984), pp. 327-342.

- "Productivity Shocks, Non-Traded Goods and Optimal Capital Accumulation," European Economic Review 30 (1986), pp. 1081-1095.

Nurkse, Ragnar, "International Investment Today in the Light of

Nineteenth-Century Experience," Economic Journal 64 (December 1954), pp. 134-150.

Obstfeld, Maurice, "Capital Mobility in the World Economy: Theory and Measurement," Carnegie-Rochester Conference Series on Public Policy 24 (Spring 1986), pp. 55-103.

- "How Integrated Are World Capital Markets? Some New Tests," in Guillermo A. Calvo et al., eds., Debt, Stabilization, and Development: Essays in Memory of Carlos Diaz-Alejandro, Oxford, Basil Blackwell, 1989, pp. 134-155.

-, "Comment," in B. Douglas Bernheim and John B. Shoven, eds., National Saving and Economic Performance, Chicago, University of Chicago Press, 1991, pp. 261-270.

- "International Risk Sharing and Capital Mobility: Another Look," Journal of International Money and Finance 11 (February 1992), pp. 115-121.

- "Are Industrial-Country Consumption Risks Globally Diversified?" in Leonardo Leiderman and Assaf Razin, eds., Capital Mobility:

Stabilizing or Volatizing?, Cambridge, Cambridge University Press, 1994.

-, "Risk-Taking, Global Diversification, and Growth," American Economic Review (forthcoming, a).

-, "Evaluating Risky Consumption Paths: The Role of Intertemporal Substitutability," European Economic Review (forthcoming, b).

Popper, Helen, "Long-Term Covered Interest Parity: Evidence from Currency Swaps," Journal of International Money and Finance 12 (August 1993), pp. 439-448. 
Razin, Assaf, and Efraim Sadka, "The Interactions between International Migration and International Trade," Research Memorandum 316, Institute for Advanced Studies, Vienna, February 1993.

Rubinstein, Mark, "An Aggregation Theorem for Securities Markets," Journal of Financial Economics 1 (September 1974), pp. 225-244.

Shiller, Robert J., "Aggregate Income Risks and Hedging Mechanisms," Cowles Foundation Discussion Paper 1048, Yale University, June 1993.

Sinn, Stefan, "Saving-Investment Correlations and Capital Mobility: On the Evidence from Annual Data," Economic Journal 102 (September 1992), pp. $1162-1170$.

Stockman, Alan C., and Harris Dellas, "International Portfolio Nondiversification and Exchange Rate Variability," Journal of International Economics 26 (May 1989), pp. 271-289.

Stockman, Alan C., and Linda L. Tesar, "Tastes and Technology in a Two-Country Model of the Business Cycle: Explaining International Comovements," NBER Working Paper 3566, December 1990.

Stulz, René M., "A Model of International Asset Pricing," Journal of Financial Economics 9 (1981), pp. 383-406.

Summers, Lawrence H., "Tax Policy and International Competitiveness," in Jacob A. Frenkel, ed., International Aspects of Fiscal Policies, Chicago, University of Chicago Press, 1988, pp. 349-375.

Summers, Robert, and Alan Heston, "The Penn World Table (Mark 5): An Expanded Set of International Comparisons, 1950-1988," Quarterly Journal of Economics 106 (May 1991), pp. 327-368.

Svensson, Lars E. O., "Trade in Risky Assets," American Economic Review 78 (June 1988), pp. 375-394.

Tesar, Linda L., "Savings, Investment, and International Capital Flows," Journal of International Economics 31 (August 1991), pp. 55-78.

-, "International Risk-Sharing and Nontraded Goods," Journal of International Economics 35 (August 1993), pp. 69-89.

Tesar, Linda L., and Ingrid M. Werner, "Home Bias and the Globalization of Securities Markets," NBER Working Paper 4218, November 1992.

Ueda, Kazuo, "A Comparative Perspective on Japanese Monetary Policy: Short-Run Monetary Control and the Transmission Mechanism," in Kenneth J. Singleton, ed., Japanese Monetary Policy, Chicago, University of Chicago Press, 1993, pp. 7-29.

van Wincoop, Eric, "Welfare Gains from International Risksharing," mimeo, Innocenzo Gasparini Institute for Economic Research, 1992a. 
_. "Regional Risksharing," mimeo, Innocenzo Gasparini Institute for Economic Research, 1992 b.

—., "International Risksharing," mimeo, Innocenzo Gasparini Institute for Economic Research, 1992c.

Vikøren, Birger, "The Saving-Investment Correlation in the Short Run and in the Long Run," mimeo, Research Department, Norges Bank, 1991.

Wong, David Y., "What Do Saving-Investment Relationships Tell Us about Capital Mobility?" Journal of International Money and Finance 9 (March 1990), pp. 60-74. 


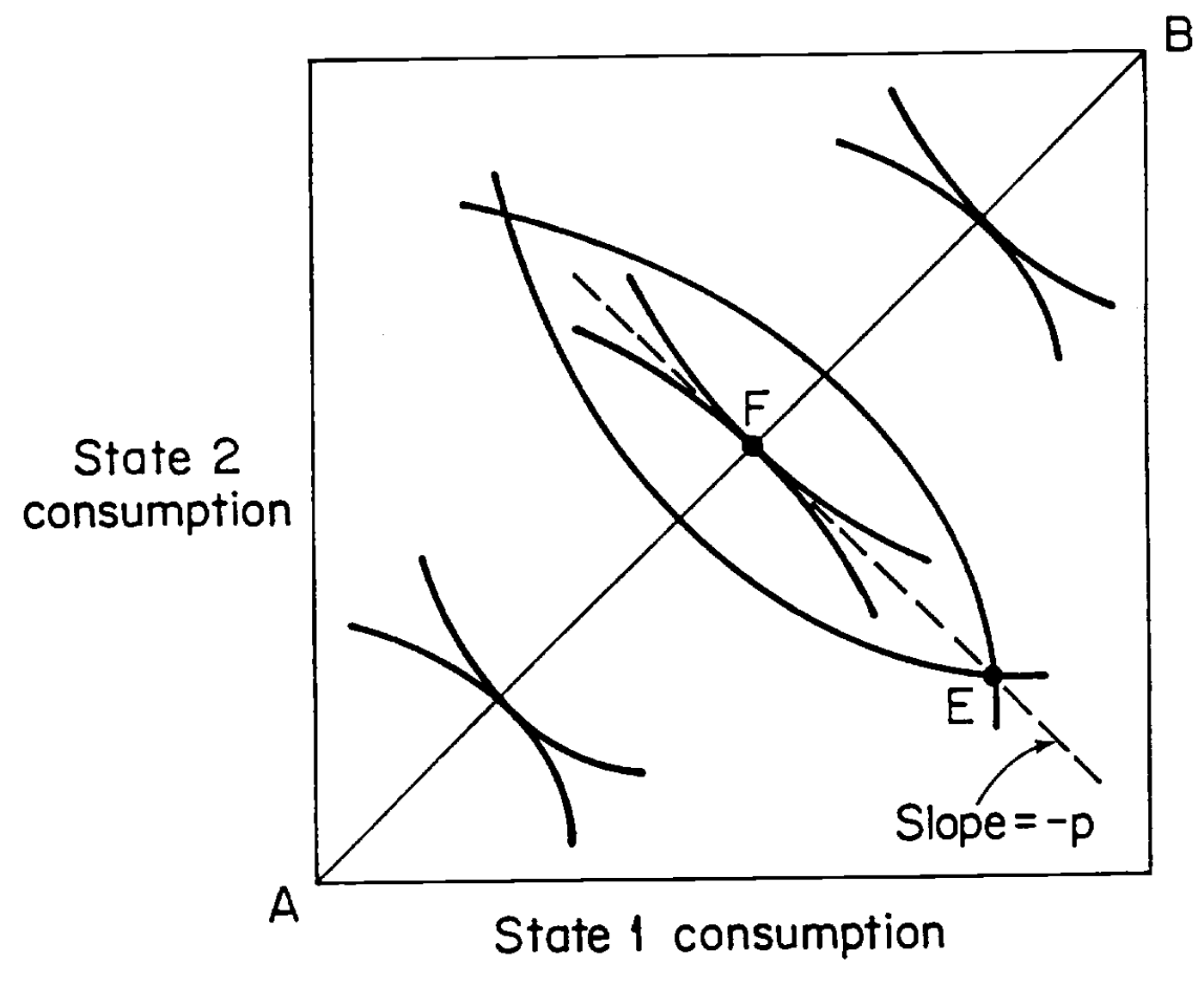

FIGURE 1: Trade across states of nature 


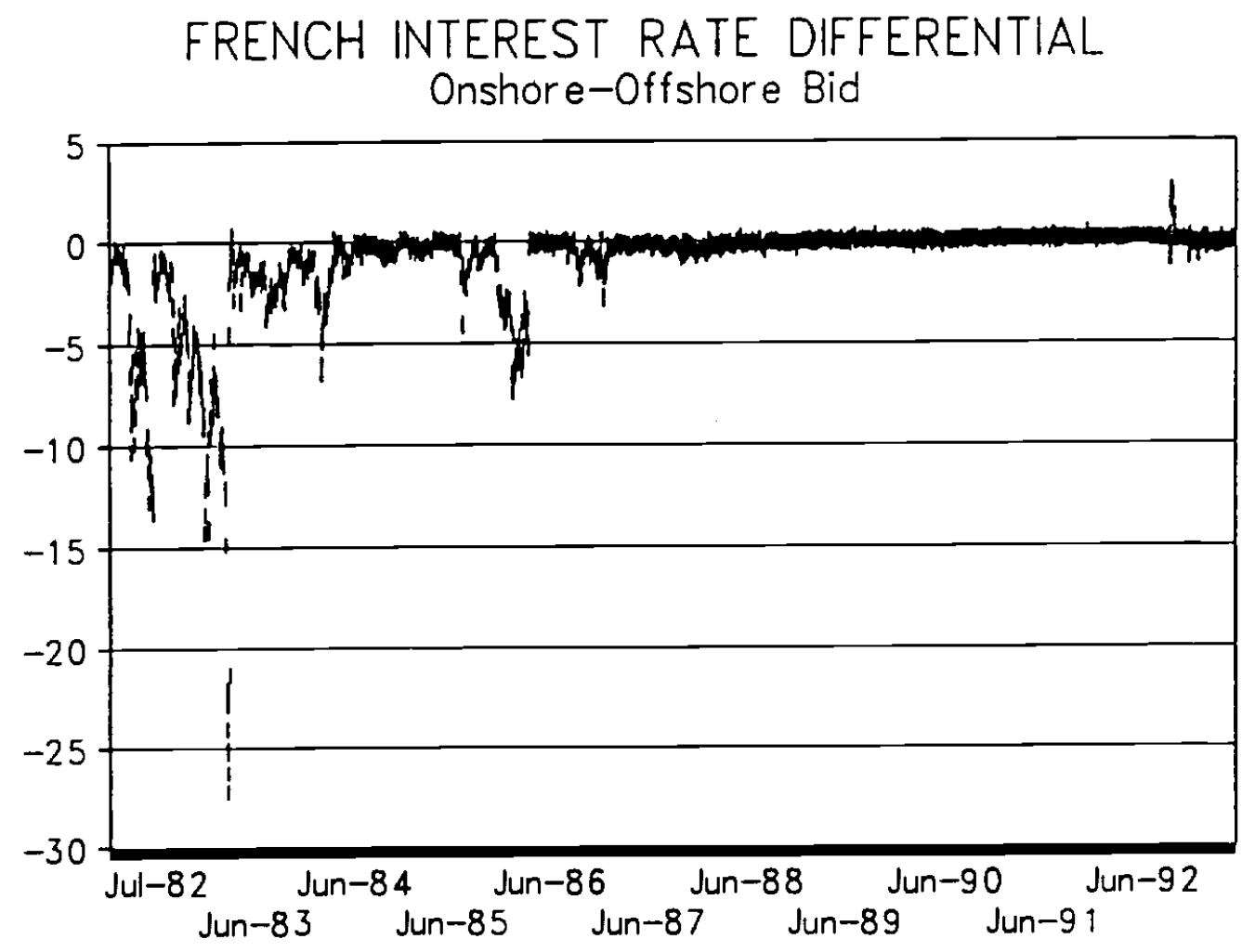

FIGURE 2: French franc onshore-offshore bid interest rate differential, January 1982-April 1993 


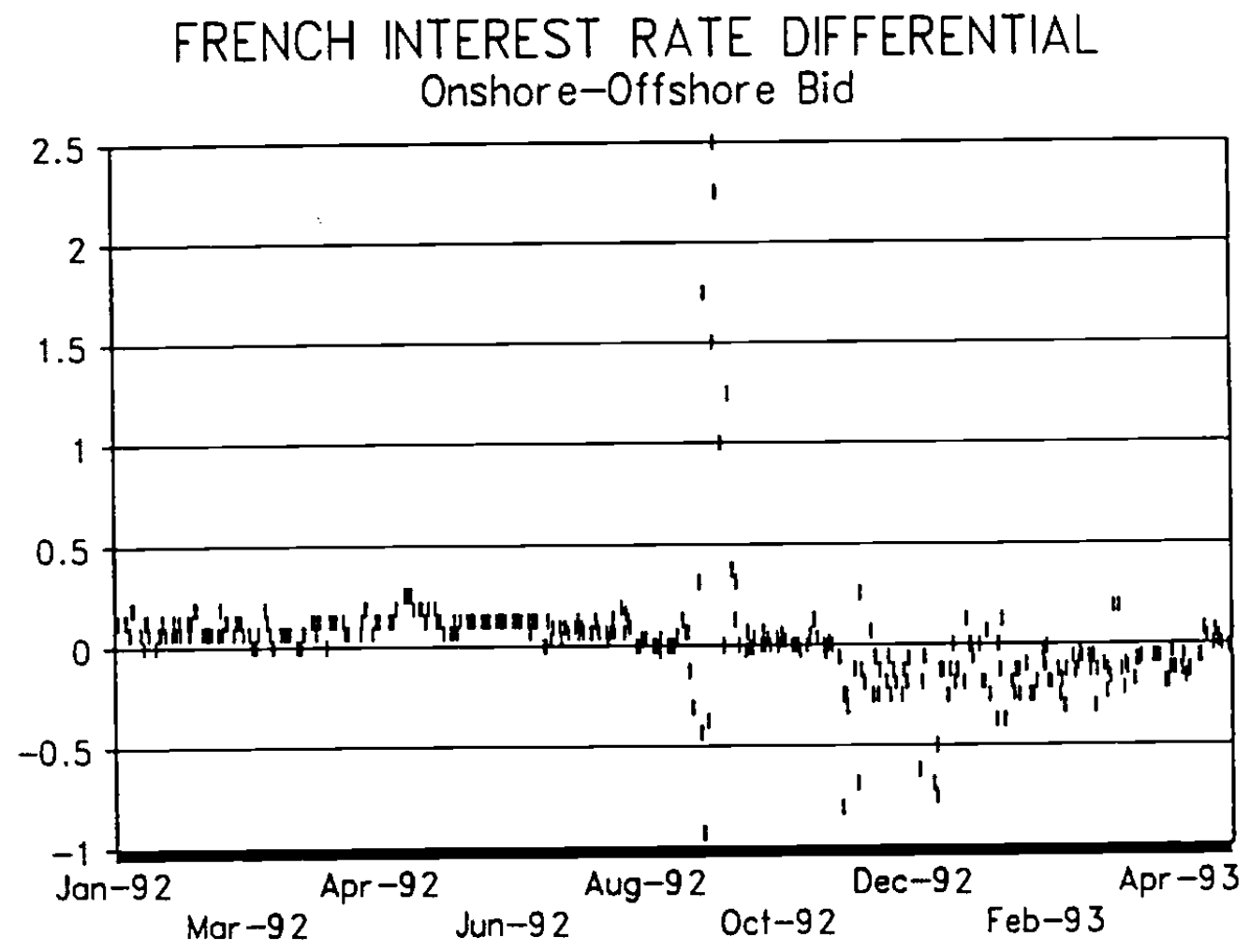

FIGURE 3: French franc onshore-offshore bid interest rate differential, January 1992-April 1993 


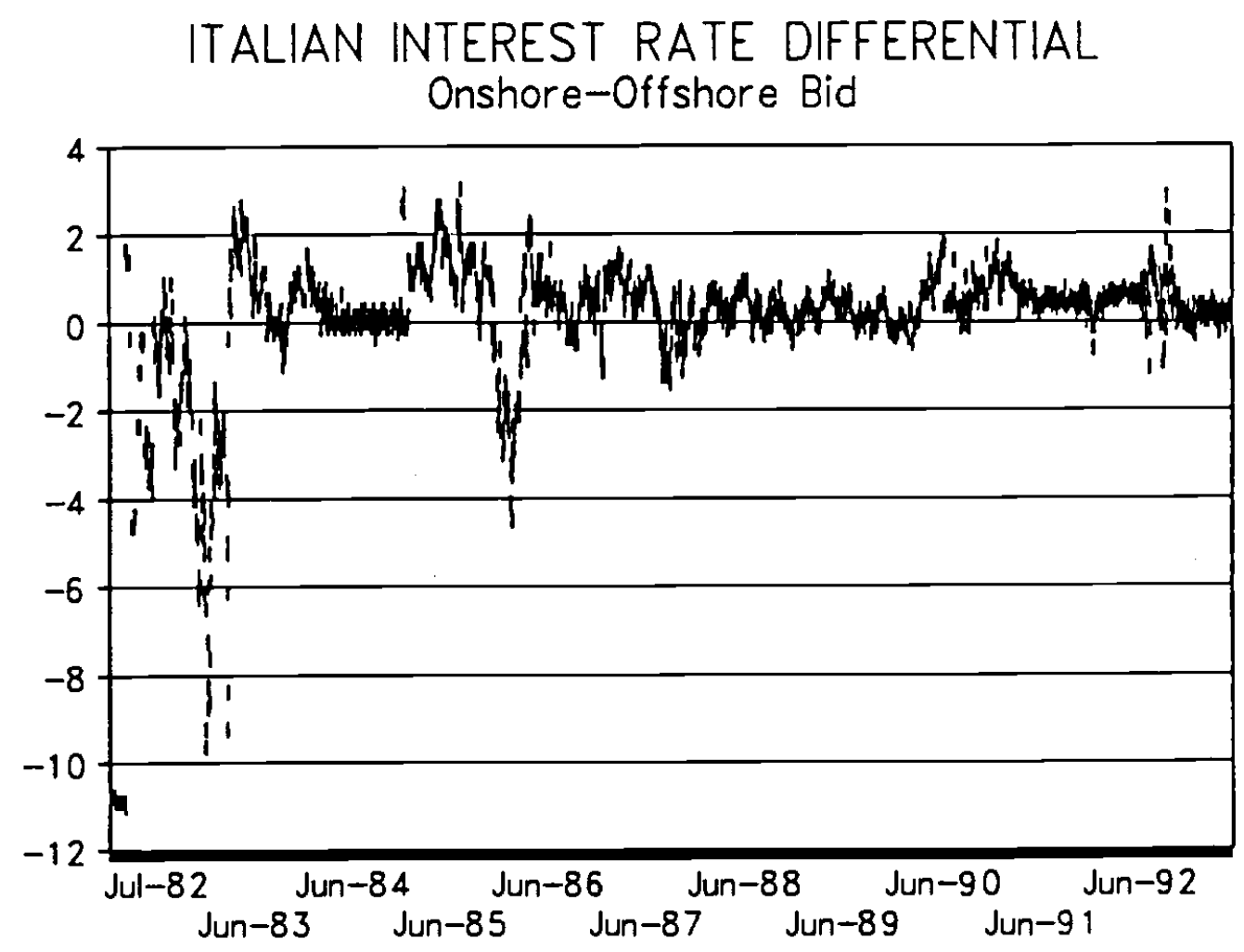

FIGURE 4: Italian lira onshore-offshore bid interest rate differential, January 1982-April 1993 


\section{GERMAN INTEREST RATE DIFFERENTIAL Onshore-Offshore Bid}

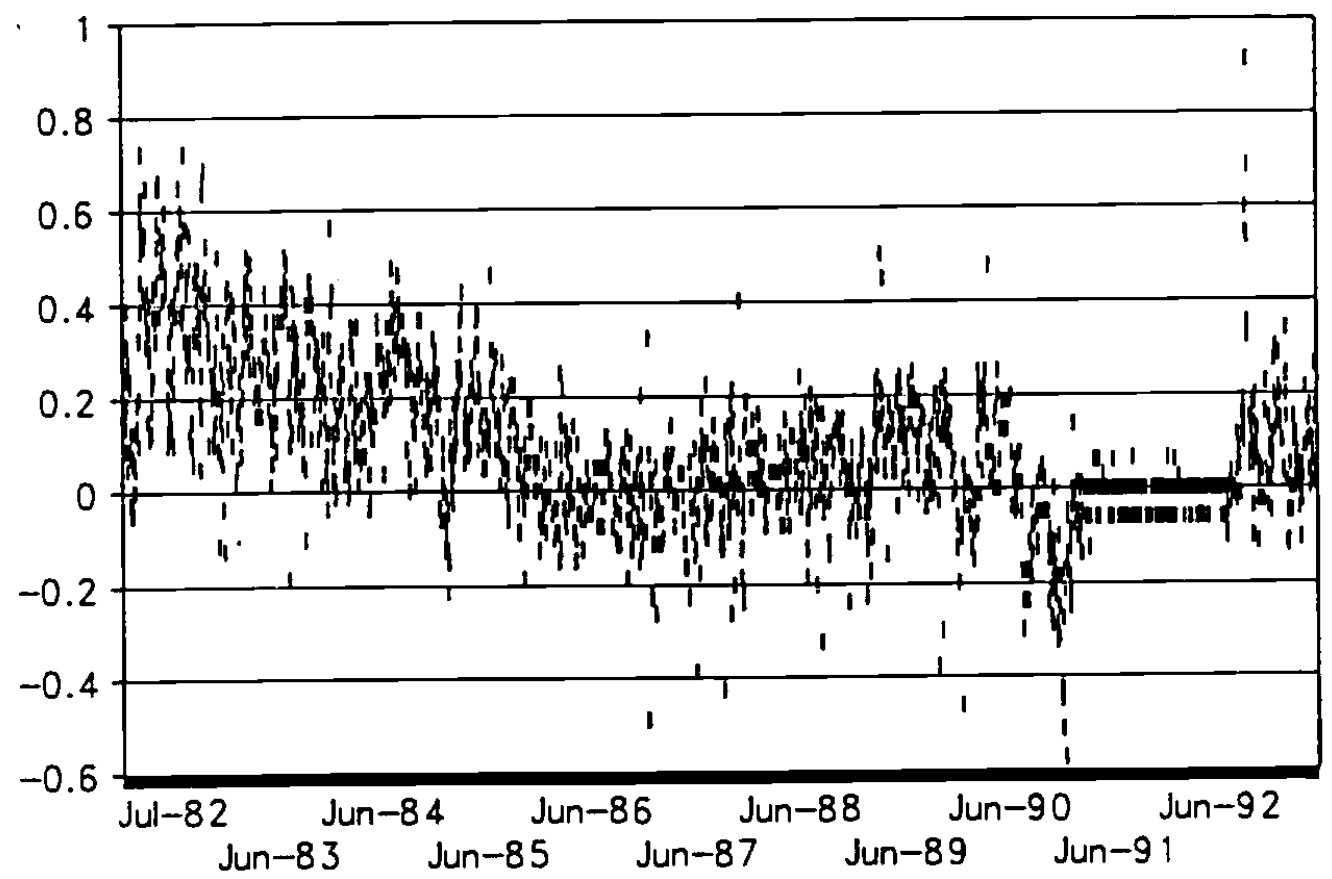

FIGURE 5: German mark onshore-offshore bid interest rate differential, January 1982-Apr 111993 


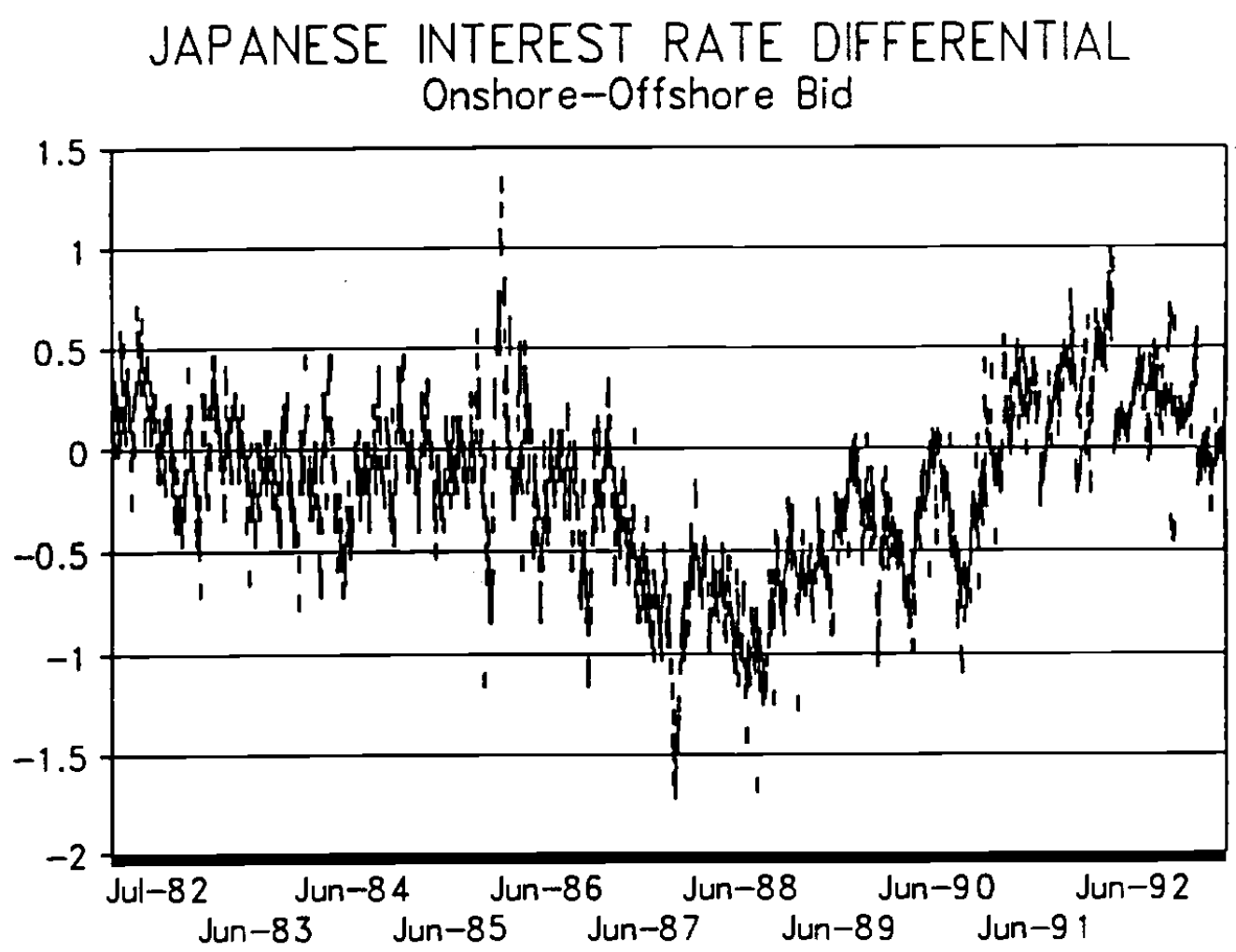

FIGURE 6: Japanese yen onshore-offshore bid interest rate differential, January 1982-Apr11 1993 


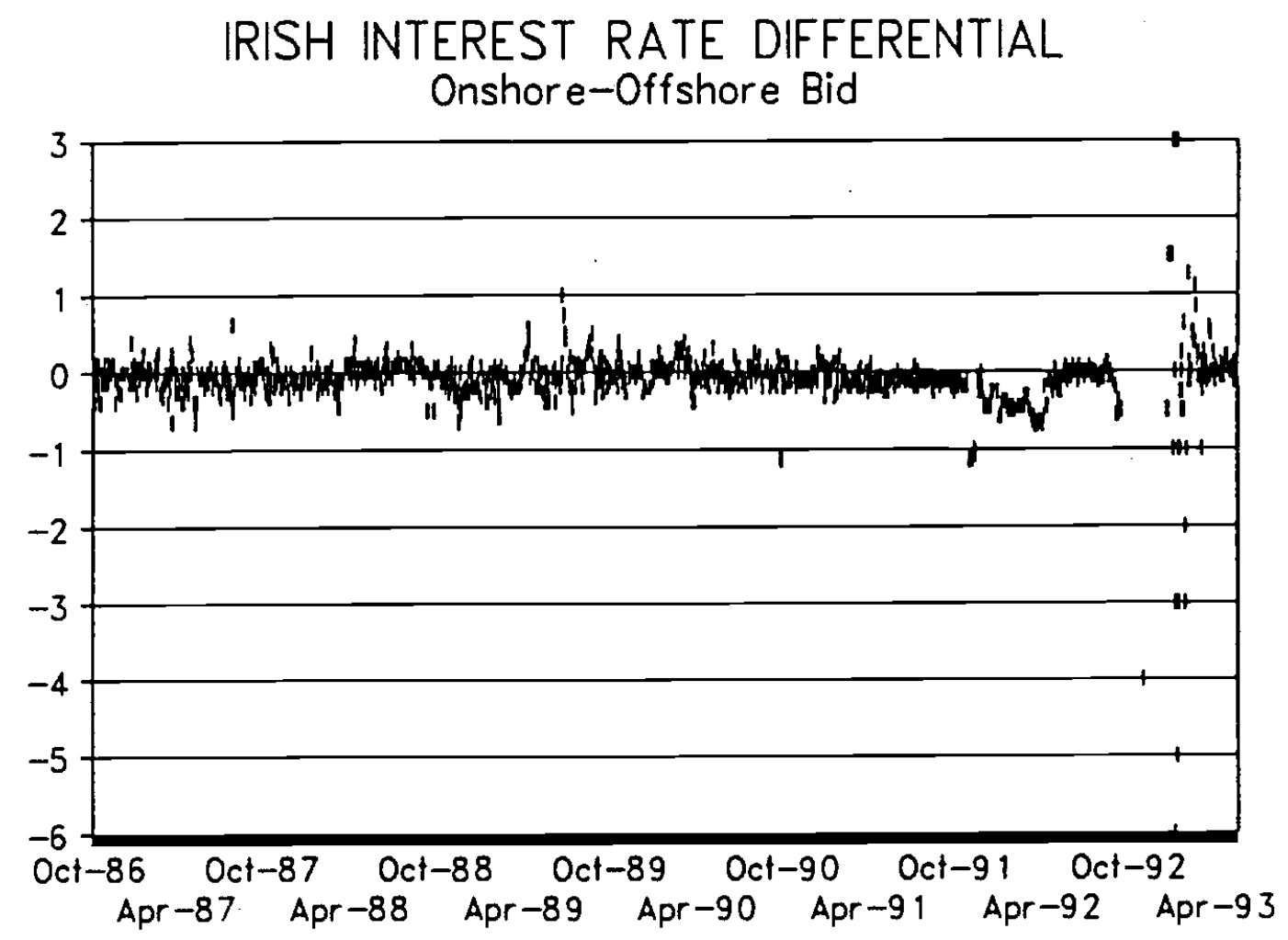

FIGURE 7: Irish punt onshore-offshore bid interest rate differential, October 1986-April 1993 
Capital-Output Ratios for Some Industrial Countries 1973 versus 1987

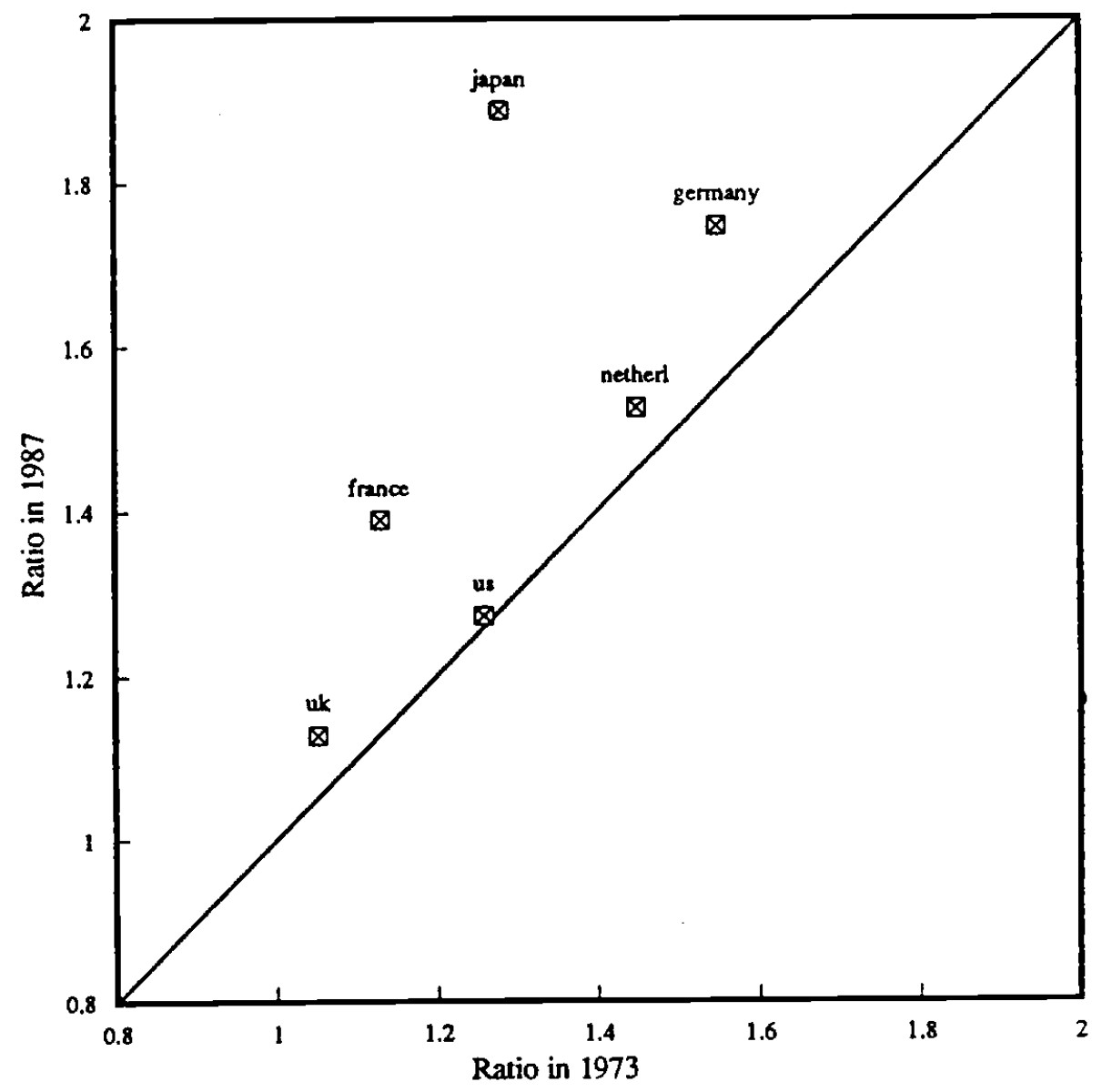

FIGURE 8: Industrial-country capltal-output ratlos, 1973 and 1987 (from Maddison 1991) 
Saving and Investment Rates for the Industrial Countries 1981-90

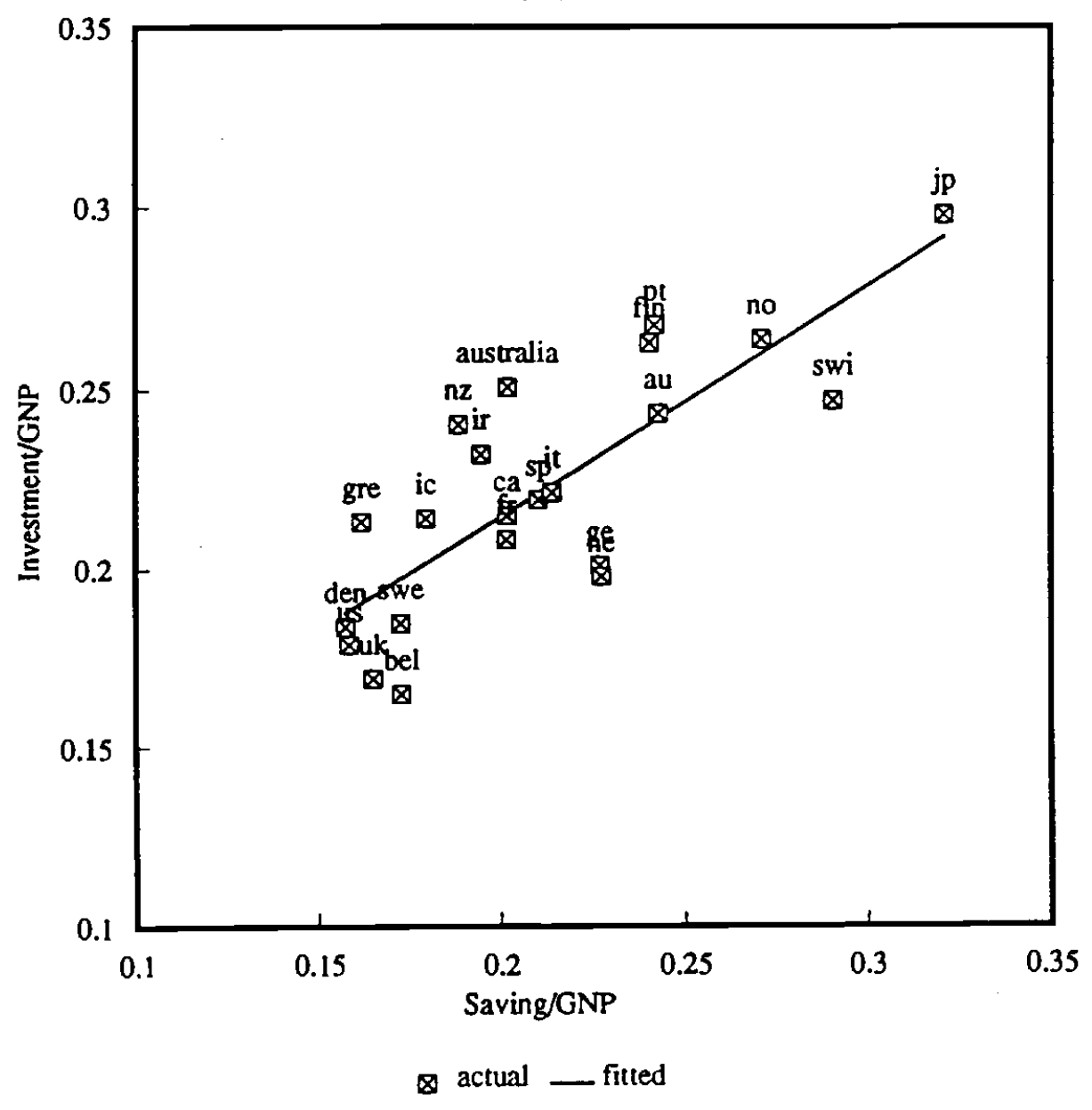

FIGURE 9: Average saving and 1nvestment rates for 22 Industrial countries, 1981-90 

FIGURE 10: Average saving and investment rates for 11 countries under the classical gold standard, 1900-13

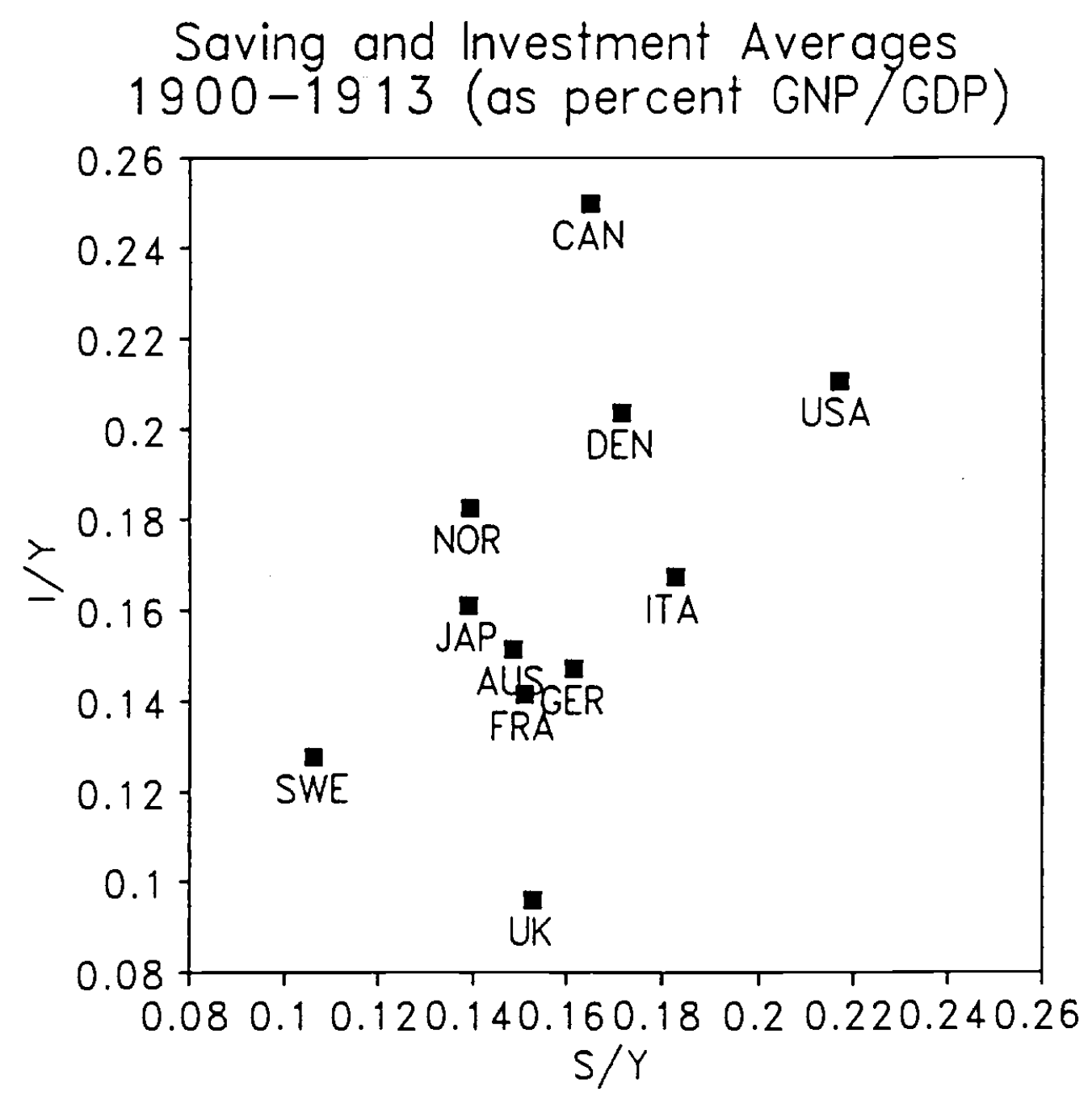


FIGURE 11: Average saving and Investment rates for 11 countries in the interwar period, 1926-38

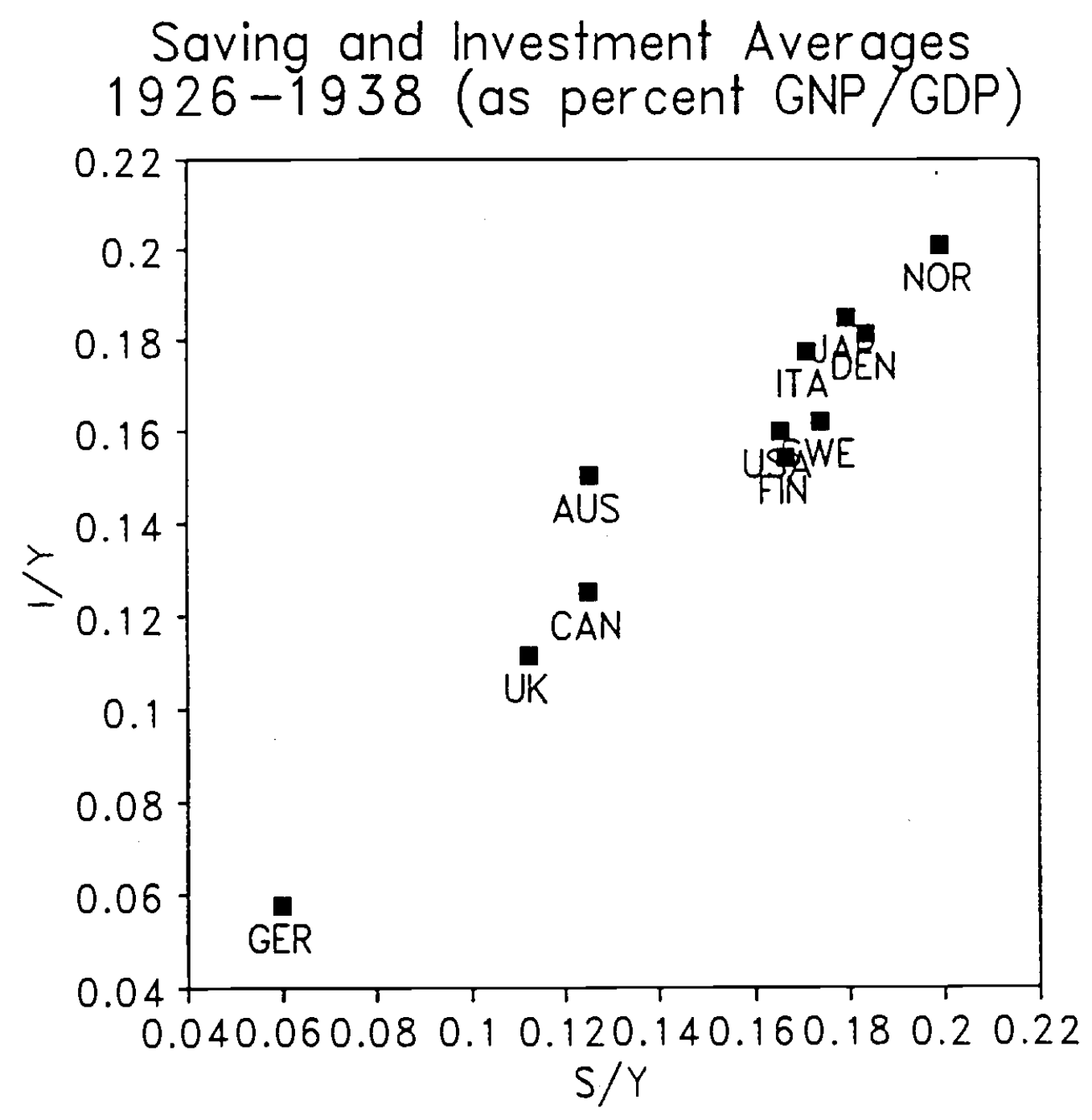


FIGURE 12: Average saving and investment rates for

45 Japanese prefectures, 1975-88

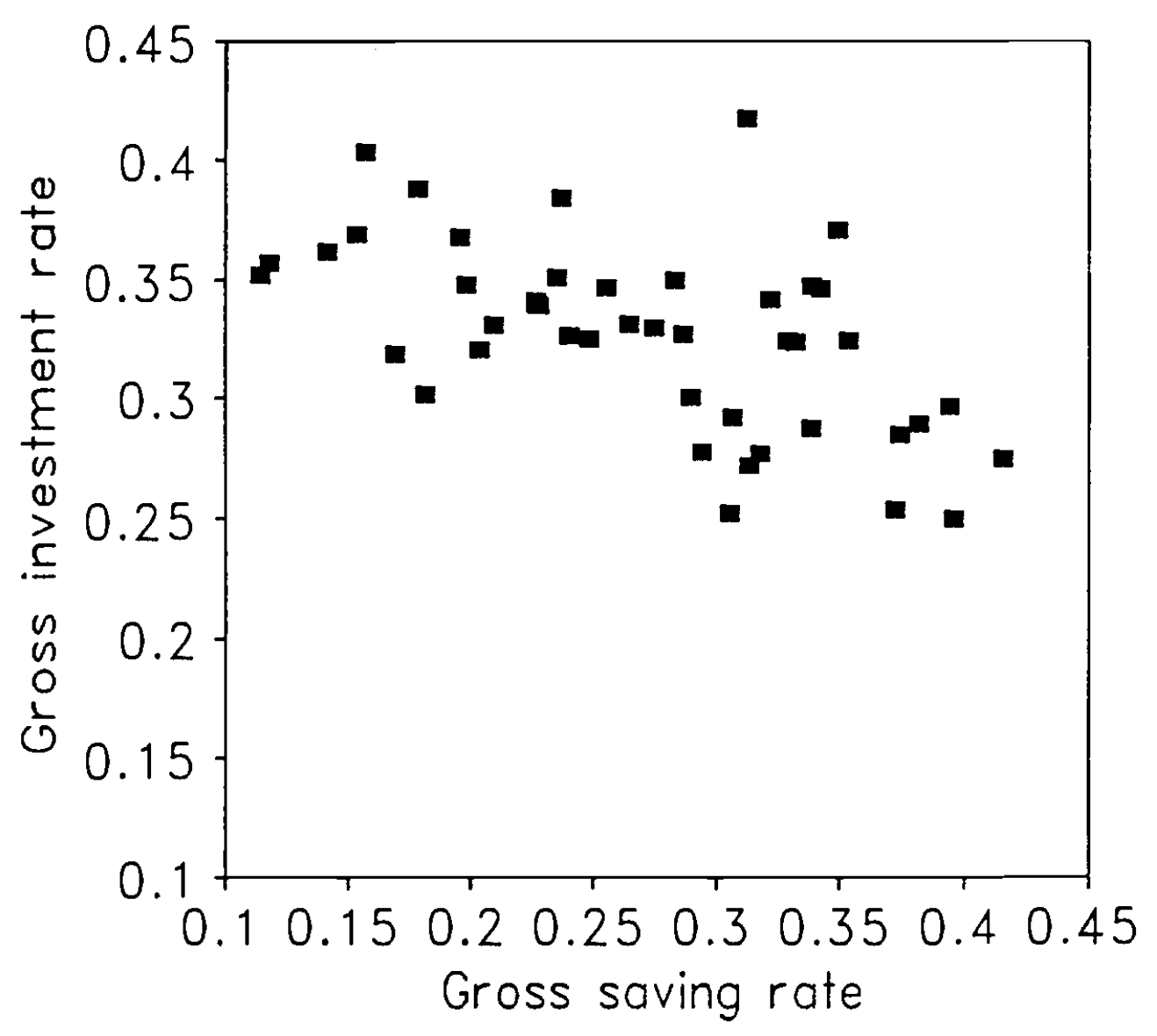


Table 1

Domestic interbank versus Eurocurrency three-month interest rates: Daily data, January 1, 1982-April 30, 1993 (in basis points)

\section{A. France}

\begin{tabular}{|c|c|c|c|c|c|c|}
\hline Period & $\underline{1}_{\mathrm{Fr}}^{F}-\frac{1}{-F r}$ & $\bar{i}_{F r}^{F}-{ }^{-E}$ & $\underline{I}_{F r}^{F}-{ }^{-E} \frac{E}{F r}$ & ${ }^{1}{ }_{F r}^{E}-{ }^{-F} \frac{F}{F r}$ & $\begin{array}{l}\text { Onshore } \\
\text { ask-bid }\end{array}$ & $\begin{array}{l}\text { Offshore } \\
\text { ask-bld }\end{array}$ \\
\hline $\begin{array}{ll}\text { Jan. } 1, & 1982- \\
\text { Jan. } 31, & 1987\end{array}$ & $\begin{array}{l}-227 \\
(336)\end{array}$ & $\begin{array}{l}-254 \\
(375)\end{array}$ & $\begin{array}{l}-267 \\
(375)\end{array}$ & $\begin{array}{c}214 \\
(336)\end{array}$ & $\begin{array}{l}13 \\
(3)\end{array}$ & $\begin{array}{c}40 \\
(49)\end{array}$ \\
\hline $\begin{array}{l}\text { Feb. } 1,1987- \\
\text { June } 30,1990\end{array}$ & $\begin{array}{l}-11 \\
(16)\end{array}$ & $\begin{array}{l}-10 \\
(20)\end{array}$ & $\begin{array}{l}-23 \\
(19)\end{array}$ & $\begin{array}{c}-2 \\
(17)\end{array}$ & $\begin{array}{l}13 \\
(4)\end{array}$ & $\begin{array}{c}13 \\
(10)\end{array}$ \\
\hline $\begin{array}{l}\text { July 1, } 1990- \\
\text { May 31, } 1992\end{array}$ & $\begin{array}{l}8 \\
(7)\end{array}$ & $\begin{array}{c}1 \\
(11)\end{array}$ & $\begin{array}{r}-11 \\
(7)\end{array}$ & $\begin{array}{l}-20 \\
(10)\end{array}$ & $\begin{array}{l}12 \\
(8)\end{array}$ & $\begin{array}{l}19 \\
(5)\end{array}$ \\
\hline $\begin{array}{l}\text { June 1, 1992- } \\
\text { Apr 11 } 30,1993\end{array}$ & $\begin{array}{c}-1 \\
(34)\end{array}$ & $\begin{array}{l}-3 \\
(40)\end{array}$ & $\begin{array}{l}-35 \\
(45)\end{array}$ & $\begin{array}{l}-32 \\
(36)\end{array}$ & $\begin{array}{c}32 \\
(20)\end{array}$ & $\begin{array}{c}34 \\
(38)\end{array}$ \\
\hline
\end{tabular}

B. Italy

\begin{tabular}{|c|c|c|c|c|c|c|}
\hline Perlod & $i_{L}^{I}-I_{L}^{E}$ & $\bar{I}_{\mathrm{L} 1^{-1}}^{-I_{\mathrm{L}}}$ & $i_{\mathrm{L} l}^{I}-\bar{i}_{\mathrm{L} 1}^{E}$ & $\underline{I}_{\mathrm{L} 1}^{E}-I_{\mathrm{L} L}^{-I}$ & $\begin{array}{l}\text { Onshore } \\
\text { ask-bid }\end{array}$ & $\begin{array}{l}\text { Offshore } \\
\text { ask-bid }\end{array}$ \\
\hline $\begin{array}{l}\text { Jan. } 1,1982- \\
\text { Jan. } 31,1987\end{array}$ & $\begin{array}{l}-50 \\
(262)\end{array}$ & $\begin{array}{c}-89 \\
(311)\end{array}$ & $\begin{array}{l}-124 \\
(308)\end{array}$ & $\begin{array}{c}15 \\
(265)\end{array}$ & $\begin{array}{c}34 \\
(10)\end{array}$ & $\begin{array}{c}74 \\
(57)\end{array}$ \\
\hline $\begin{array}{l}\text { Feb. } 1,1987- \\
\text { June } 30,1990\end{array}$ & $\begin{array}{l}29 \\
(48)\end{array}$ & $\begin{array}{c}48 \\
(47)\end{array}$ & $\begin{array}{l}-14 \\
(49)\end{array}$ & $\begin{array}{l}-91 \\
(47)\end{array}$ & $\begin{array}{c}62 \\
(20)\end{array}$ & $\begin{array}{l}43 \\
(7)\end{array}$ \\
\hline $\begin{array}{l}\text { July 1, } 1990- \\
\text { May 31, } 1992\end{array}$ & $\begin{array}{c}56 \\
(29)\end{array}$ & $\begin{array}{c}63 \\
(36)\end{array}$ & $\begin{array}{c}9 \\
(29)\end{array}$ & $\begin{array}{r}-111 \\
(37)\end{array}$ & $\begin{array}{c}55 \\
(24)\end{array}$ & $\begin{array}{l}47 \\
(6)\end{array}$ \\
\hline $\begin{array}{l}\text { June 1, 1992- } \\
\text { Apr } 1130,1993\end{array}$ & $\begin{array}{c}36 \\
(49)\end{array}$ & $\begin{array}{c}28 \\
(50)\end{array}$ & $\begin{array}{l}-8 \\
(43)\end{array}$ & $\begin{array}{l}-73 \\
(62)\end{array}$ & $\begin{array}{c}36 \\
(42)\end{array}$ & $\begin{array}{c}45 \\
(33)\end{array}$ \\
\hline
\end{tabular}


Table 1 (continued)

C. Germany

\begin{tabular}{|c|c|c|c|c|c|c|}
\hline Perlod & $\underline{1}_{-\mathrm{DM}}^{\mathrm{G}}-\frac{1}{-} \mathrm{DM}$ & $\overline{1}_{\mathrm{DM}}^{-\mathrm{G}} \frac{-\mathrm{E}}{\mathrm{DM}}$ & $\underline{1}_{-\mathrm{DM}}^{\mathrm{G}}-\frac{-\mathrm{E}}{\mathrm{DM}}$ & $\stackrel{1}{-D M}^{-1} \mathrm{DM}$ & $\begin{array}{l}\text { Onshore } \\
\text { ask-b1d }\end{array}$ & $\begin{array}{l}\text { Offshore } \\
\text { ask-bid }\end{array}$ \\
\hline $\begin{array}{llr}\text { Jan. } & 1, & 1982- \\
J a n . & 31, & 1987\end{array}$ & $\begin{array}{c}17 \\
(17)\end{array}$ & $\begin{array}{c}16 \\
(17)\end{array}$ & $\begin{array}{c}5 \\
(18)\end{array}$ & $\begin{array}{l}-28 \\
(16)\end{array}$ & $\begin{array}{l}11 \\
(4)\end{array}$ & $\begin{array}{l}13 \\
(3)\end{array}$ \\
\hline $\begin{array}{ll}\text { Feb. } 1, & 1987- \\
\text { June } & 30,1990\end{array}$ & $\begin{array}{c}5 \\
(10)\end{array}$ & $\begin{array}{c}3 \\
(10)\end{array}$ & $\begin{array}{l}-8 \\
(11)\end{array}$ & $\begin{array}{l}-15 \\
(10)\end{array}$ & $\begin{array}{l}10 \\
(2)\end{array}$ & $\begin{array}{l}13 \\
(3)\end{array}$ \\
\hline $\begin{array}{l}\text { July 1, } 1990- \\
\text { May 31, } 1992\end{array}$ & $\begin{array}{l}-5 \\
(9)\end{array}$ & $\begin{array}{l}-5 \\
(8)\end{array}$ & $\begin{array}{r}-18 \\
(9)\end{array}$ & $\begin{array}{l}-8 \\
(8)\end{array}$ & $\begin{array}{l}13 \\
(2)\end{array}$ & $\begin{array}{l}13 \\
(1)\end{array}$ \\
\hline $\begin{array}{l}\text { June } 1,1992- \\
\text { Apr 1 } 30,1993\end{array}$ & $\begin{array}{c}7 \\
(13)\end{array}$ & $\begin{array}{c}5 \\
(12)\end{array}$ & $\begin{array}{c}-6 \\
(12)\end{array}$ & $\begin{array}{l}-18 \\
(13)\end{array}$ & $\begin{array}{l}11 \\
(2)\end{array}$ & $\begin{array}{l}13 \\
(2)\end{array}$ \\
\hline \multicolumn{7}{|c|}{ D. Japan } \\
\hline Perlod & $\underline{1}_{\gamma}^{J}-\underline{1}_{\gamma}^{E}$ & $\overline{1}_{Y}^{J}-\bar{I}_{V}^{E}$ & $\underline{1}_{Y}^{J}-i_{Y}^{-E}$ & $\underline{1}_{\gamma}^{E}-\bar{I}_{\gamma}^{J}$ & $\begin{array}{l}\text { Onshore } \\
\text { ask-bid }\end{array}$ & $\begin{array}{l}\text { Offshore } \\
\text { ask-bid }\end{array}$ \\
\hline $\begin{array}{l}\text { Jan. } 1,1982- \\
\text { Jan. } 31,1987\end{array}$ & $\begin{array}{l}-7 \\
(28)\end{array}$ & na & $\begin{array}{l}-20 \\
(28)\end{array}$ & na & na & $\begin{array}{l}13 \\
(4)\end{array}$ \\
\hline $\begin{array}{l}\text { Feb. } 1,1987- \\
\text { June } 30,1990\end{array}$ & $\begin{array}{l}-60 \\
(33)\end{array}$ & na & $\begin{array}{l}-68 \\
(33)\end{array}$ & na & na & $\begin{array}{c}8 \\
(3)\end{array}$ \\
\hline $\begin{array}{l}\text { July 1, } 1990- \\
\text { May 31, } 1992\end{array}$ & $\begin{array}{c}9 \\
(37)\end{array}$ & na & $\begin{array}{c}2 \\
(37)\end{array}$ & na & na & $\begin{array}{c}7 \\
(3)\end{array}$ \\
\hline $\begin{array}{l}\text { June } 1,1992- \\
\text { Aprl1 } 30,1993\end{array}$ & $\begin{array}{c}17 \\
(19)\end{array}$ & na & $\begin{array}{c}10 \\
(19)\end{array}$ & na & na & $\begin{array}{c}7 \\
(2)\end{array}$ \\
\hline
\end{tabular}

Note: Numbers in parentheses are standard deviations. Subscripts denote asset currency of denomination (Fr = franc, $L 1=11$ ra, $D M=$ deutsche mark, $\gamma=$ yen); superscripts denote asset location ( $E=$ London Eurocurrency market, $F=$ France $, I=I t a l y, G=$ Germany, $J=$ Japan). Overbars denote ask interest rates (the rates at which banks lend funds), underbars bid interest rates (the rates banks pay on deposits). Data are dally except for weekends and hol idays. 
Table 2

Consumption and output correlations:

International data, 1951-72 and 1973-88

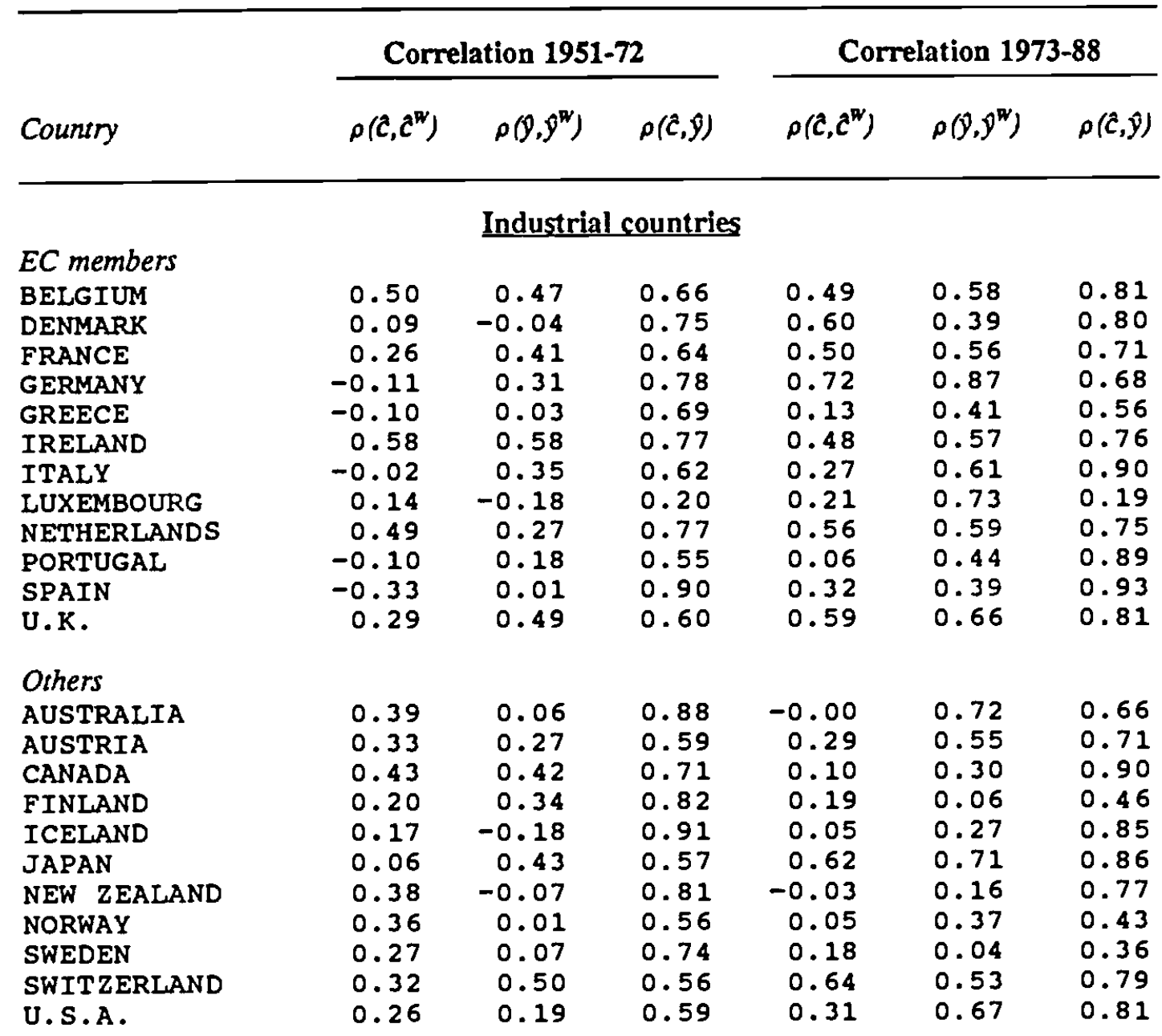

Developing countries

$\begin{array}{lrrrrrr}\text { ARGENTINA } & 0.00 & 0.02 & 0.96 & -0.04 & 0.25 & 0.92 \\ \text { BOLIVIA } & -0.07 & 0.34 & 0.59 & 0.29 & 0.08 & 0.74 \\ \text { CHILE } & -0.32 & 0.02 & 0.69 & 0.44 & 0.62 & 0.85 \\ \text { COLOMBIA } & 0.28 & 0.11 & 0.89 & 0.29 & 0.51 & 0.79 \\ \text { COSTA RICA } & 0.15 & -0.09 & 0.89 & 0.63 & 0.65 & 0.95 \\ \text { CYPRUS } & 0.20 & -0.04 & 0.62 & 0.64 & 0.64 & 0.92 \\ \text { DOMINICAN REP. } & 0.03 & 0.10 & 0.92 & 0.11 & 0.26 & 0.88 \\ \text { ECUADOR } & -0.01 & 0.19 & 0.63 & -0.17 & 0.05 & 0.67 \\ \text { EL SALVADOR } & 0.38 & 0.21 & 0.89 & 0.56 & 0.44 & 0.95\end{array}$


Table 2 (continued)

\begin{tabular}{|c|c|c|c|c|c|c|}
\hline \multirow[b]{2}{*}{ Country } & \multicolumn{3}{|c|}{ Correlation 1951-72 } & \multicolumn{3}{|c|}{ Correlation 1973-88 } \\
\hline & $\rho\left(\hat{c}, \hat{c}^{\mathbb{W}}\right)$ & $\rho\left(\varphi, \hat{y}^{\mathbb{N}}\right)$ & $\rho(\hat{c}, \hat{y})$ & $\rho\left(\hat{c}, \hat{c}^{\mathrm{W}}\right)$ & $\rho\left(\hat{y}, \hat{y}^{\mathbb{W}}\right)$ & $\rho(\hat{c}, \hat{y})$ \\
\hline GUATEMALA & -0.28 & -0.40 & 0.81 & 0.39 & 0.48 & 0.95 \\
\hline HONDURAS & 0.16 & 0.20 & 0.58 & 0.54 & 0.68 & 0.91 \\
\hline INDIA & -0.13 & -0.09 & 0.59 & -0.13 & -0.16 & 0.93 \\
\hline KENYA & -0.04 & 0.24 & 0.93 & -0.08 & 0.20 & 0.82 \\
\hline MEXICO & -0.01 & 0.22 & 0.92 & -0.27 & 0.02 & 0.98 \\
\hline MOROCCO & -0.18 & -0.05 & 0.94 & 0.22 & -0.04 & 0.62 \\
\hline PARAGUAY & 0.13 & -0.21 & 0.78 & -0.32 & 0.01 & 0.93 \\
\hline PAKISTAN & 0.03 & 0.33 & 0.59 & -0.20 & 0.06 & 0.44 \\
\hline PERU & 0.11 & 0.35 & 0.60 & -0.26 & -0.18 & 0.94 \\
\hline PHILIPPINES & 0.03 & -0.15 & 0.77 & -0.06 & -0.12 & 0.80 \\
\hline SOUTH AFRICA & 0.39 & 0.20 & 0.85 & -0.49 & -0.10 & 0.88 \\
\hline THAILAND & -0.27 & -0.23 & 0.94 & 0.51 & 0.61 & 0.84 \\
\hline TRINIDAD\&TOBAGO & -0.20 & -0.09 & 0.69 & -0.30 & -0.33 & 0.95 \\
\hline TURKEY & -0.13 & 0.21 & 0.96 & 0.06 & -0.18 & 0.86 \\
\hline URUGUAY & 0.17 & 0.42 & 0.95 & 0.09 & 0.28 & 0.90 \\
\hline
\end{tabular}

Note: The numbers $\rho\left(c, c^{N}\right)$ [or $\rho\left(\xi, \hat{q}^{\text {N }}\right)$ ] are simple correlation coefficients between the annual change in the natural logarithm of the country's real per capita consumption (or output) and the annual change in the natural logarithm of the rest of the world's real per capita consumption (or output), with the "world" defined as the sample listed in the table. National per capita consumptions and outputs were calculated using variables 1,3, and 6 listed in appendix A.1 of summers and Heston (1991). The numbers $\rho(c, \hat{y})$ are correlations between each country's log consumption per capita and log output per capita changes. 
rable 3

Consumption and income correlations by prefecture: Japanese data, 1975-88

\begin{tabular}{|c|c|c|c|c|c|c|c|}
\hline Prefecture & $\rho\left(\hat{c}, \hat{c}^{\prime}\right)$ & $\rho\left(\hat{y}, \hat{y}^{\prime}\right)$ & $\rho(\hat{c}, \hat{y})$ & Prefecture & $\rho\left(\hat{c}, \hat{c}^{\prime}\right)$ & $\rho\left(\theta, y^{\prime}\right)$ & $\rho(\hat{c}, \hat{y})$ \\
\hline Hokkaido & 0.595 & .165 & 0.339 & 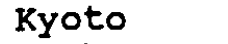 & 0.682 & 0.149 & \\
\hline Aomori & -0.096 & 0.196 & 0.905 & Osaka & 0.719 & 0.053 & 0.776 \\
\hline & 0.750 & 0.555 & 0.420 & Hyogo & 0.480 & -0.000 & 0.742 \\
\hline 18 & 0.219 & 0.433 & 0.367 & Nara & 0.181 & 0.766 & -0.211 \\
\hline imagata & 0.496 & 0.303 & 0.748 & akayama & 0.136 & 0.105 & 0.455 \\
\hline ima & 0.065 & .386 & 0.898 & rottori & 0.413 & 0.858 & 0.491 \\
\hline & 0.077 & .205 & 0.630 & hima & 0.170 & 0.551 & 0.717 \\
\hline higi & 0.100 & 0.115 & -0.589 & Okayama & 0.245 & 0.103 & -0.568 \\
\hline & 0.644 & 0.668 & 0.444 & Hiroshima & 0.661 & 0.075 & 0.736 \\
\hline ima & 0.404 & 0.337 & 0.696 & Yamaguchi & 0.777 & 0.331 & -0.201 \\
\hline & 0.547 & 0.267 & 0.693 & Tokushima & 0.313 & 0.613 & 0.705 \\
\hline & 0.238 & 0.055 & 0.978 & Kagawa & 0.610 & 0.494 & 0.555 \\
\hline gawa & 0.240 & -0.015 & 0.872 & Ehime & 0.277 & 0.215 & 0.577 \\
\hline $\operatorname{sh} i$ & 0.658 & 0.513 & 0.567 & Kochi & 0.070 & 0.122 & 0.115 \\
\hline & 0.252 & 0.358 & -0.474 & Fukuoka & 0.319 & 0.123 & 0.569 \\
\hline Shizuoka & 0.297 & 0.415 & & Saga & & 0.534 & 0.913 \\
\hline Toyama & 0.098 & 0.232 & -0.713 & Nagasaki & -0.218 & 0.254 & 0.704 \\
\hline Ishikawa & 0.723 & 0.380 & 0.764 & Kumamoto & 0.059 & 0.221 & 0.907 \\
\hline & 0.258 & 0.423 & -0.313 & Oita & -0.020 & 0.096 & 0.537 \\
\hline & 0.349 & -0.004 & -0.265 & Miyazaki & 0.010 & 0.528 & 0.824 \\
\hline & 0.039 & 0.211 & -0.618 & Kagoshima & 0.046 & 0.218 & 0.982 \\
\hline Fukui & 0.012 & -0.106 & 0.849 & okinawa & -0.249 & 0.036 & 0.949 \\
\hline
\end{tabular}

Note: The numbers $\rho\left(c, c^{\prime}\right)$ [or $\rho\left(q, q^{\prime}\right)$ ] are simple correlation coefficients between the annual change in the natural logarithm of the prefecture's real per capita consumption (or income) and the annual change in the natural logarithm of the other 44 prefectures' average real per capita consumption (or income). The numbers $\rho(c, \hat{q})$ are correlations between prefecture log consumption per capita and log income per capita changes. Data supplied by Robert Dekle. 
Table 4

Galns from the elimination of consumption variablitit:

selected developing countries

Country

Bot swana

Kenya

Morocco

Tanzania

zimbabwe

Bangladesh

India

Malayeia

Thalland

Turkey

Barbados

Mexico

Argentina

Braz11

Chile

Venezuela
4.56

4.27

1.54

4.53

5.31

3.04

0.93

1.17

1.07

1.52

2.69

0.54

1.94

1.80

2.75

2.22

Note: The calculations asaume that the logarithm of per capita consumption follows a random walk with trend and that individuals have generalized isoelastic utility functions with annual time discount factor 0.95 , relative risk aversion parameter 1 , and intertemporal substitution elasticity 0.25 . Data are taken from sumers and Heston (1991). For detalls on the calculation see obstfeld (forthcoming). 
Table 5

Cross-sectional regressions of investment rates on saving rates: Period average data, 1974-90

\begin{tabular}{lcc}
\hline Period & $\hat{\beta}^{\text {cs }}$ & $R^{2}$ \\
\hline \multirow{2}{*}{$1974-90$} & 0.715 & 0.60 \\
& $(0.131)$ & \\
$1974-80$ & 0.867 & 0.56 \\
& $(0.170)$ & 0.64 \\
$1981-90$ & 0.636 & 0.43 \\
& $(0.108)$ & 0.657 \\
$1981-85$ & $(0.147)$ & 0.69 \\
& 0.636 & \\
\hline
\end{tabular}

Note: Estimates of equation (4) in text. Standard errors appear in parentheses below eatimates of slope coefficient $\beta$ cs. The sample of 22 countries consiats of Australia, Austria, Belgium, canada, Denmark, Finland, France, Germany, Greece, Iceland, Ireland, Italy, Japan, the Netherlands, New zealand, Norway, Portugal, Spain, sweden, Switzerland, the 0.K., and the o.s. 
Table 6

Time-series regressions of investment rates on saving rates: Annual data, 1974-90

\begin{tabular}{lcc}
\hline & $\beta^{\text {Ts }}($ levels) & $\beta^{\text {Ts }}$ (differences) \\
Country & & \\
& & \\
Australia & 0.792 & 0.857 \\
Austria & 0.825 & 0.732 \\
Belgium & 0.637 & 0.749 \\
Canada & 1.097 & 0.963 \\
Denmark & 0.727 & 0.657 \\
Finland & 1.803 & 1.172 \\
France & 0.909 & 1.101 \\
Germany & 0.327 & 0.561 \\
Greece & 0.845 & 0.892 \\
Iceland & -0.450 & -0.654 \\
Ireland & -0.037 & 0.208 \\
Italy & 0.214 & 1.154 \\
Japan & 1.161 & 1.100 \\
Luxembourg & -0.135 & 0.042 \\
Netherlands & 0.381 & 0.457 \\
New zealand & 1.154 & 0.787 \\
Norway & -0.614 & -0.515 \\
Portugal & 0.736 & 0.718 \\
Spain & 1.104 & 0.246 \\
Sweden & 0.717 & 0.574 \\
Switzerland & 1.221 & 1.547 \\
United Kingdom & 0.113 & 1.002 \\
United States & 0.848 & 1.090 \\
& & \\
\hline
\end{tabular}

Note: "Levels" estimates are based on the ols regresiion

$(I / Y)_{t}=\alpha^{2 s}+\beta^{T s}(S / Y)_{t}+\gamma^{T s_{t}}+u_{t}$, "differences" estimates on the OLS regresBion $\Delta(I / Y)_{t}=\alpha^{T S}+\beta^{T S} \Delta(S / Y)_{t}+\Delta u_{t}$. 
Table 7

Time-series correlation coefficlents between saving and investment rates: Annual data, 1974-90

\begin{tabular}{|c|c|c|}
\hline Country & $\hat{p}^{2 s}$ (levels) & $\hat{p}^{\text {Ts }}$ (differences) \\
\hline $\begin{array}{l}\text { Australia } \\
\text { Austria } \\
\text { Belgium } \\
\text { Canada } \\
\text { Denmark } \\
\text { Pinland } \\
\text { Irance } \\
\text { Germany } \\
\text { Greece } \\
\text { Iceland } \\
\text { Ireland } \\
\text { Italy } \\
\text { Japan } \\
\text { Luxembourg } \\
\text { Netherlands } \\
\text { New zealand } \\
\text { Norway } \\
\text { Portugal } \\
\text { Spain } \\
\text { Sweden } \\
\text { Switzerland } \\
\text { United Ringdom } \\
\text { United States }\end{array}$ & $\begin{array}{r}0.834 \\
0.746 \\
0.848 \\
0.745 \\
0.783 \\
0.846 \\
0.851 \\
0.401 \\
0.836 \\
-0.333 \\
-0.031 \\
0.150 \\
0.837 \\
-0.247 \\
0.505 \\
0.517 \\
-0.659 \\
0.591 \\
0.711 \\
0.785 \\
0.784 \\
0.092 \\
0.773\end{array}$ & $\begin{array}{r}0.742 \\
0.575 \\
0.773 \\
0.823 \\
0.662 \\
0.682 \\
0.710 \\
0.610 \\
0.750 \\
-0.333 \\
0.157 \\
0.560 \\
0.795 \\
0.071 \\
0.518 \\
0.562 \\
-0.474 \\
0.584 \\
0.193 \\
0.514 \\
0.736 \\
0.668 \\
0.895\end{array}$ \\
\hline
\end{tabular}

Note: "Levels" estimates are simple correlation coefficients between $(I / Y)_{t}$ and $(S / Y)_{t}$, where both variables are linearly detrended. "Differences" estimates are correlation coefficients between $\Delta(I / Y)_{t}$ and $\Delta(S / Y)_{t}$. 


\section{Table 8}

Cross-gectional regressions of investment rates on saving rates during the classical gold standard and interwar period: Perlod average data

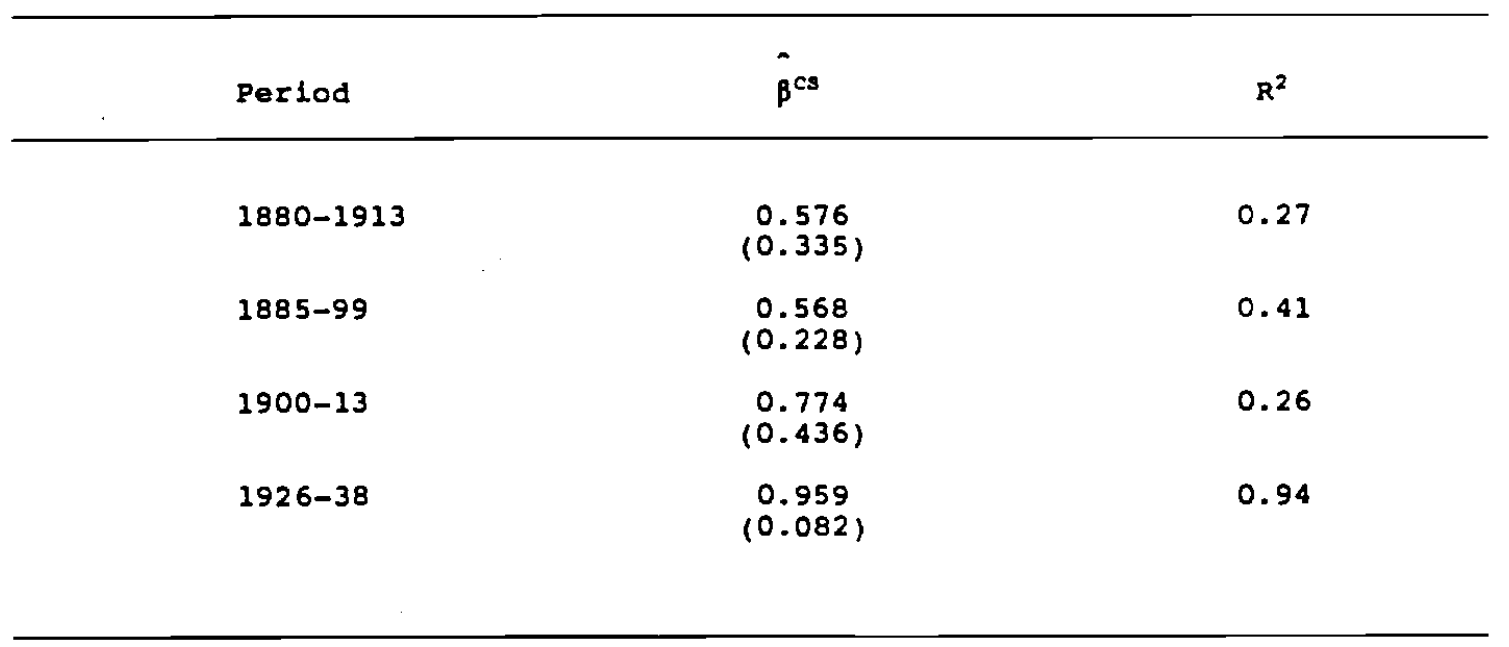

Note: Estimates of equation (4) in text. standard errors appear in parentheses below estimates of alope coefficient $\beta^{\mathrm{cs}}$. The 1880-1913 Bample consists of Australla, Canada, Denmark, France, Germany, Italy, Norway, Sweden, the U.X., and the U.S. The 1885-99 and 190013 samples add Japan. The 1926-38 sample aubtracts France and adds Finland. 